\title{
Challenges and potentials in using alternative landscape futures during climate change: A literature review and survey study
}

This study focuses on the feasibility of applying alternative futures and scenario analysis in landscape planning during climate change to provide a wider perspective and deeper understanding of this approach for better use and more effective application in the future. The study consists of a literature review and an analysis of recent applied projects carried out worldwide. In addition, an electronic survey was conducted from March to September 2014 to examine viewpoints on the use and application of this approach with reference to climate-change impacts. The survey participants were a group of highly experienced researchers from eighteen countries involved in at least one applied project since 2000 relating to this topic. After analysis of more than forty applied projects, the survey results were incorporated into the analysis to create a comprehensive picture regarding the potentials and limitations of alternative futures and scenario analysis in landscape planning with particular attention to climate change. The findings show that this method is one of the most effective decision-making approaches for adopting landscape policies where landscapes change rapidly under the pressure of urbanisation and climate change. Nevertheless, there is a gap between the advances offered by the approach in various dimensions and the complexity of patterns, uncertainties and upheavals in landscapes due to climate-change impacts in the urbanising world. The research indicates that the approach opens up a great opportunity for decision-makers to expand their perspective and adopt appropriate landscape policies before reaching a point of no return from the sustainability point of view. Meanwhile, there are challenges and barriers in the application of alternative futures and scenario analysis for envisioning the landscapes influenced by climate change and urbanisation that should be pushed back. Although informative, this research raises new questions about this approach and its applications in the future, providing a basis for further research.

Keywords: alternative landscape futures, scenario analysis, climate change, urbanisation, survey study, experts' viewpoint 


\section{Introduction}

The world is increasingly becoming urbanised like never before (see Mulligan \& Crampton, 2005; Pimentel \& Pimentel, 2006). The growing demand for living in urban regions due to their inherent socioeconomic attractions (see, e.g., Acharya \& Barragán Codina, 2012; Cheng, 2012; Zhang et al., 2012) has had far-reaching consequences for natural landscapes in recent years, and this has generated a great impetus for researchers to come up with new methods and techniques to measure, predict, depict and manage changes in landscape patterns and processes (e.g., Turner, 1989; Jenerette \& Wu, 2001; Bender et al., 2005; Deng et al., 2008; Jenerette \& Potere, 2010). Since 2000, some ecologically based studies have especially emphasised the relationship between haphazard urban development and the depletion of natural resources worldwide (e.g., Dale et al., 2000; Pickett et al., 2001; Jongman, 2002; Alberti \& Marzluff, 2004; Kupfer, 2006; Ahern, 2007; Breuste et al., 2008; Mehaffy \& Haas, 2012; Obeng-Odoom, 2012). In line with this trend, climate-change impacts on the urbanised world have also been examined. Climate change is one of the most powerful driving forces behind land-use and land-cover change, and it has led to unprecedented landscape upheaval in urbanised landscapes. Floods, droughts, storms and rises in sea level are major consequences of climate change in urban areas worldwide (see Hamin \& Gurran, 2009). Recently, some researchers have sought new ways to find a sustainable cure for this destructive phenomenon. Among all of the efforts, some researchers show that making assumptions about possible changes in landscapes with particular attention to climate-change impacts and other important variables, and then envisioning these changes in landscapes, can be a sufficient means of informing decision-makers about the likely effects of each set of landscape policies on the entire landscape beforehand (e.g., Bryan et al., 2008; Morley et al., 2012). Landscape policies can address climate change. Similarly, climate change can result in a wide range of landscape changes. Therefore, under conditions of urbanisation and climate change, envisioning changes in landscapes caused by both urbanisation and climate change provides a basis for informed decisions on adopting appropriate landscape policies. Because each set of land-use and land-cover policies causes specific changes in a landscape, it is clear that the level of landscape vulnerability and resiliency in the face of climate-change impacts is different in each case. Therefore, depicting the likely effects of these policies on a landscape's future can be an integral part of mitigation and adaptation strategies when planning urbanised landscapes. To adopt sustainable landscape policies against the adverse effects of climate change, it is necessary to explore and understand the rules governing landscape change over time.
Incorporating information about landscape ecology into landscape planning may hold the key to addressing climate-change impacts on cities through mitigation and adaptation strategies (see Opdam et al., 2009). Addressing climate change, urban development and landscape ecology simultaneously may make it possible to overcome current landscape-planning dilemmas. In response to climate change-induced urban and regional challenges, this research proposes using alternative futures and scenario analysis as an efficient tool supporting informed decisions on land-use and land-cover policies. Defining alternative futures for landscapes under climate-change pressure can inform society concerning what the future might bring. Applying this approach can ensure the accuracy and reliability of landscape policies formulated based upon technological facilities, social values, ecological knowledge and collective wisdom. Nevertheless, there remain many questions regarding the use and application of this approach for making informed decisions about the interrelationships between landscape change, urbanisation and climate change based on envisioning different landscape futures. This research addresses two major questions: 1) Is alternative futures and scenario analysis an appropriate and reliable tool for depicting future landscapes, and consequently adopting landscape-planning policies during climate change? 2) What are the current challenges and potentials in applying this decision-making tool in the real world?

\section{Methodology}

In this study, the term landscape refers to a combination of various anthropogenic land uses and natural land covers interacting with each other in a large scale over time. The research combines international literature and information from experts' practical experiences to provide better insight into the role of alternative futures and scenario analysis in ecologically based landscape planning with regard to climate change. A multi-approach strategy was used for the research. The study's cornerstone was an in-depth review of case studies using an alternative futures and scenario analysis approach in different countries. The case studies were analysed in detail by applying a content-analysis method. Then, to strengthen the review, an informative survey was carried out with the collaboration of a small number of experienced experts worldwide.

Multiple sources of information were used (see Wang \& Hofe, 2007; Deming \& Swaffield, 2011) to collect the required data. To start with, a wide array of publications, including recently published papers in peer-reviewed journals, well-established books and technical reports, were collected, filtered, classified and reviewed. After reviewing the international literature, key concepts were derived using a complex description strategy 
to provide a basis for designing an informative questionnaire. A twenty-four-question e-questionnaire, with various types of questions, was circulated via e-mail to relevant persons. Questionnaires were sent to a broad group of potential participants, ranging from university instructors to professionals in landscape architecture, urban and regional planning, biodiversity conservation, soil sciences, habitat management, bioagriculture, geology, geography, rural planning and landscape restoration.

One of the strengths of the questionnaire was the diversity of question types, such as closed-ended, open-ended, yes/ no, and ranking-based questions. Closed-ended questions were designed based on a Likert scale to systematically obtain experts' judgments concerning important issues. More importantly, to scrutinise the issues studied in detail, several open-ended questions were also used to reveal matters that are unlikely to be discovered using ordinary multiple-choice questions. To find relevant individuals whose academic and professional experiences were appropriate for inclusion in the survey, a keyword-based search was used in well-established scientific databases such as Science Direct to find the name of authors that published their research in peer-reviewed journals since the late 1990s. To increase the accuracy of research to the highest possible degree, a filter question was also designed at the beginning of the questionnaire. This question asked respondents to complete the questionnaire only if they had been involved in at least one applied alternative landscape futures project since 2000. In addition, to avoid omitting influential people in this area, a snowballing approach was applied to identify additional relevant persons. The researcher thus asked participants to suggest relevant persons whose work and experience were relevant to this study. The snowballing approach was used to identify overlooked relevant persons and expand the search. By using the snowballing approach, several participants were added.

Ultimately, forty-two respondents from eighteen countries returned questionnaires (Table 1). Among them, thirty-one participants answered all of the questions on the questionnaire and eleven questionnaires were incomplete. Incomplete questionnaires were excluded from in-depth analysis and the study concentrated on thirty-one questionnaires. Nonetheless, useful information from the incomplete questionnaires was also taken into consideration. Whereas in ordinary surveys sample size is calculated by a formula, statistical tables, and referring to similar studies or a combination of such methods, in research when the respondents are highly qualified and wellinformed it is enough to reach a saturation point (see Flick, 1998; Guest et al., 2006) where the researcher does not observe new items in responses. Moreover, when responses are repeated in a regular pattern, this can be considered a sign of achieving
Table 1: Geographical distribution of participants

\begin{tabular}{|c|c|c|}
\hline Region & Country & Number \\
\hline \multirow{2}{*}{ North America } & Canada & 2 \\
\hline & US & 10 \\
\hline \multirow{14}{*}{ Europe } & Czech Republic & 1 \\
\hline & Estonia & 1 \\
\hline & Finland & 2 \\
\hline & France & 3 \\
\hline & Germany & 3 \\
\hline & Italy & 4 \\
\hline & Latvia & 1 \\
\hline & Netherlands & 2 \\
\hline & Slovakia & 1 \\
\hline & Slovenia & 1 \\
\hline & Spain & 1 \\
\hline & Sweden & 2 \\
\hline & Switzerland & 1 \\
\hline & UK & 2 \\
\hline Oceania & Australia & 4 \\
\hline Asia & Japan & 1 \\
\hline
\end{tabular}

an acceptable level of error in sampling. From another angle, because the sample was geographically diverse, this ensured the reliability of the survey. Furthermore, the diversity of participants in various academic disciplines also potentially guaranteed the accuracy of survey results. In this study, the responses were monitored by the researcher while questionnaires were gradually sent to appropriate persons. More than six months of research went into achieving the saturation point where it was no longer necessary to increase the sample size.

Statistical graphics and conceptual figures were used to visualise useful information. The survey results reflect a broad range of concerns relating to the use of alternative futures in landscape planning with reference to future climate change. Overall, the combination of key concepts derived from in-depth analysis of applied case studies plus information gained from the survey represents the most important potential feature of using alternative futures and scenario analysis in landscape planning during climate change.

\section{Mapping the historical trend}

Alternative futures and scenario analysis is an approach for making informed decisions regarding possible futures. According to Remi Barre (2004: 116, cited in Kosow \& Gabner, 2008), "scenarios allow for looking far and wide". In many cases, "they provide support for more long-term and more system-oriented observations than other approaches" (Kosow \& Gabner, 2008: 19). Sandra Greeuw et al. (2000: 7) 
emphasise the fact that "the approach is perhaps most effective when seen as a powerful tool to broaden perspectives, raise questions and challenge conventional wisdom." Various variables and factors should be taken into consideration when addressing the use and application of alternative futures and scenario analysis in the contemporary history of landscape planning. In general, the academic emergence of alternative futures and scenario analysis can be seen in William F. Ogburn's research on social trends and their consequences in the US from 1930 to 1933 (Odum, 1951). During the 1950s and 1960s, this approach was applied in business management and marketing. The book The Limits to Growth (Meadows et al., 1972) was another initiative for using alternative futures and scenario analysis in the twentieth century. The book offered a computer-aided simulation of the outcomes of the interactions between environmental and human systems. The book took world population, pollution, industrialisation, resource depletion and food production into consideration as major variables in constructing an exponential model. Nevertheless, using alternative futures in landscape planning was dependent on requirements and technological tools that developed later over three decades, from the 1960s onwards.

Along with the invention of primitive computers, quantitative techniques in landscape planning were developed during the 1960s (Fabos, 1985). This, in turn, was a quantum leap towards envisioning landscapes in later decades. In line with this development, a geographic information system (GIS) was introduced by Roger Tomlinson (1968) in Canada. One year later, the book Design with Nature was written by Ian McHarg (1969) in support of applying ecological knowledge in landscape planning. McHarg (1969) proposed a sieving technique to analyse the relationship between various layers of a landscape, ranging from fully natural to anthropogenic features. During the 1970s, GIS was developed by many researchers across the world. Breakthroughs in nonlinear systems, fractals and chaos theory started in the 1980s, and led to significant progress in urban modelling (Liu, 2009: 16) and landscape simulation. Since then, cellular automata (CA), as a powerful technique for landscape simulation, has been used to model urban growth and landscape change. These advancements paved the way for using alternative futures in landscape planning. Concurrent with these trends, the term climate change was first used by the geochemist Wallace Broecker (1975) and this led to defining a new branch of knowledge involving climate change and landscape planning. Afterwards, several seminal publications linked urban development and landscape planning to climate change from various angles (e.g., Crichton et al., 2009; Condon et al., 2009; Hodson \& Marvin, 2010; Wilson \& Piper, 2010; Calthorpe, 2011; Rosenzweig et al., 2011; Watson \& Adams, 2011; Cartwright et al., 2012; Moser \& Boykoff, 2013; Lee, 2014;
Prutsch et al., 2014). In particular, application of alternative futures and scenario analysis in landscape planning emerged in the 1990s (Botequilha Leitão \& Ahern, 2002) in the Netherlands (Harms et al., 1993; Schooenboom, 1995) and the US (Landis, 1995; Steinitz et al., 1996; Freemark et al., 1996; Hulse et al., 1997; Ahern, 1997; White et al., 1997; Ahern, 1999). Afterwards, the approach was widely used across the US (e.g., Hulse et al., 2000; Theobold \& Hobbs, 2002; Hunter et al., 2003; Steinitz et al., 2003; Aycrigg et al., 2004; Berger \& Bolte, 2004; Hulse et al., 2004; Nassauer \& Corry, 2004; Reyes et al., 2004; Santlemann et al., 2004; Schumaker et al., 2004; Corry \& Nassauer, 2005; Kepner et al., 2008; Hulse et al., 2009; Sleeter et al., 2012; Penteado, 2013), in Australia and Europe (e.g., Patel et al., 2007; Bryan et al., 2008; Soliva et al., 2008; Verburg et al., 2010; Oana et al., 2011; Morley et al., 2012), in Asia (e.g., Wang, 2011; Sun et al., 2012; Pan et al., 2014; Shoyama \& Yamagata, 2014) and even in the developing world (e.g., Ferraz et al., 2005; Bao Le et al., 2010; Sheikh-Goodarzi et al., 2012).

Alternative futures and scenario analysis has been recognised as an important contribution to landscape research. For example, Elen Deming and Simon Swaffield (2011: 111) define it as a "distinctive application of dynamic simulation modelling used to improve understanding about the landscape consequences of different policy decisions." Applying alternative futures in landscape planning has been a multipurpose approach to addressing a broad range of landscape-related issues. Either directly or indirectly, most of them are related to climate change. A review of recent studies conducted by researchers shows that the metrics by which climate change are measured have been explored. David Theobald and Thompson Hobbs (2002), for example, examined the importance of biodiversity protection on private land in the Lower Blue Basin. They emphasise the crucial role of stakeholders throughout the study. In another study, Carl Steinitz et al. (2003) placed particular emphasis on water and biodiversity in the Upper San Pedro River Basin, recognising urbanisation and agricultural activities as the major environmental stresses affecting the region. In that study, biodiversity was considered as a main criterion during the investigation. In some instances (e.g., Hunter et al., 2003), alternative futures have been postulated to establish a relationship between demographic dynamics and land-use change associated with it. The influence of land-use change on natural habitats in particular has been studied. Lori Hunter et al. (2003) concluded from their study of California's Mojave Desert that desert environments have a fragile ecology and are therefore susceptible to human pressures. They suggest that high-density development could reduce conflict with such regions by over $80 \%$, providing a potential habitat for threatened or endangered species. A study by Joan Nassauer and Robert Corry (2004) demonstrated the application of normative sce- 
narios in landscape ecology in Iowa agricultural watersheds using three scenarios: production, water quality and biodiversity. David Hulse et al. (2004) applied alternative landscape futures in the Willamette River Basin to examine the likely effects of various sets of land- and water-use policies on the landscape future. This study is an example of applying alternative futures in landscape planning due to the diversity and quantity of participants while making assumptions, as well as the considerable number of land-cover types defined for maps. More importantly, the research provides a conservation and restoration opportunities map created for use in a conservation scenario showing the importance of climate change-related concerns among researchers.

Robert Lilieholm et al. (2005) studied the relationship between urban development and the protection of environmental quality and public health in Utah to identify the likely conflicts between these variables over time. Emphasising the quality of life, this research presented a framework for envisioning the likely effects of urban development on environmental conditions. Focusing on the concept of sustainability in applying alternative futures in the Georgia Basin in British Columbia, Tara Sharma et al. (2005) argue that one of the main advantages of applying alternative futures in landscape planning is that this approach provides a basis for stakeholders to adopt informed land-use decisions and policies for the transition to a sustainable future. In a socio-environmental study, David Mouat et al. (2006) addressed the relationship between desertification and poverty using alternative futures. William Kepner et al. (2008) addressed potential water quality problems as a result of land-cover change in the American Pacific Northwest to provide options that could be useful for sustainable management of natural resources.

This review demonstrates that all alternative futures studies have concentrated on the concept of collective wisdom in landscape planning. Joan Baker et al. (2004) believe that community decision-making typically involves stakeholders with widely divergent viewpoints and values. The most important end product is developing consensus, or compromise, about desired goals and priorities; that is, shared vision for the future. The purpose of an alternative futures analysis is to facilitate this consensus-building. Mouat et al. (2006) believe that analysis of alternative futures is a forum for exchanging concerns, issues, and hopes for the future.

Having examined the advantages and strengths of using alternative futures in landscape planning over more than two decades, this approach can be applied in landscape envisioning relating to the likely effects of climate change. Over the last decade, applying alternative futures and scenario analysis for envisioning landscape policies with regard to climate change impacts has increased. In Australia, two major alternative landscape futures studies in Lower Murray (Bryan et al., 2008) and New South Wales (Morley et al., 2012) are clear examples proving that climate change and its effects on landscapes have become the most important concern among researchers, authorities and policymakers. For example, Brett Bryan et al. (2008) address dry land areas and focus on climate change as a major factor affecting landscapes. Philip Morley et al. (2012) carried out a study on alternative landscape futures and climate change adaptation to show how alternative futures and scenario analysis can be a powerful tool for anticipating climate change impacts on coastal settlements and communities. Another alternative futures-centred study in Australia (Meyer et al., 2013) discussed the importance of addressing food production and conservation during climate change. The study invited other researchers to engage in new research on the current gaps and challenges in applying this approach. This trend can be also seen in European studies. In the UK, in a case study of the Humberhead Levels, Trudie Dockerty et al. (2006) documented an approach to constructing scenarios that can incorporate potential climate change impacts and reflect the uncertainty in climate change projections due to different environmental policies. Peter Verburg et al. (2010) argue that land-use change in Europe is affected by a variety of local conditions and global processes. They took climate change into consideration as an important factor affecting these variables. There is also further evidence indicating that applying alternative futures for climate change with particular concentration on spatially explicit landscape patterns has been recognised as a priority and necessity in landscape planning. In addition to these studies, there are still questions that should be answered in the future. Some important challenges, gaps and potentials relating to the use and application of alternative futures and scenario analysis in landscape planning with reference to climate change are discussed below.

\section{Results and discussion}

Applying alternative futures and scenario analysis is an emerging approach for addressing the likely effects of climate change on urbanising landscapes. Since the 1990s, many studies have been conducted on alternative landscape futures and scenario analysis around the world, especially in developed countries. Although the majority of studies have minor differences in practice, a similar mechanism was used in all projects. In this study, this mechanism was represented in four main parts: definition, depiction, evaluation and synthesis (Table 2). The following section summarises the results of the research. The results consist of diverse findings from a comprehensive review of the international literature, an analysis of applied projects and survey findings. For better understanding and functional- 
ity, the results derived from data analysis and a literature review are presented in as descriptive a manner as possible.

\subsection{Definition \\ 4.1.1 Data collection}

To collect various types of data, including verbal and environmental, various methods and tools should be applied. From ordinary data such as demographic trends, the trajectory of change in land price, housing demands, dwelling patterns and water consumption, to more specific climate change-related data such as climate change-induced immigration rate, energy demand, food security, the change in rainfall and temperature patterns, and the volume of greenhouse gas emission, should all be taken into consideration. In this process, it is important to constantly overlap verbal and environmental data to ensure that the accuracy of data is at an acceptable level. In the case of verbal data, it is also important to define a suitable framework for stakeholder participation in decision-making. Stakeholders are social forces and can be classified into four major groups: laypeople, influential persons, experts and local authorities. To reach a consensus among such a large group of stakeholders around the issues investigated, a comprehensive plan should be mapped to guarantee the active and effective role of each group in the entire process. Experiences from previous landscape-planning projects show that researchers constantly faced difficulties during data collection (e.g., Hulse et al., 2004; Sheikh-Goodarzi et al., 2012). Paying particular attention to climate-change impacts can make the situation even more difficult because climate change-related data are not available everywhere. Moreover, collecting the relevant data is time-consuming and expensive in many cases because researchers have to rely on technological tools such as satellite images, visual and numerical data, and technical maps. In addition, the methods by which accurate data are collected are extremely diverse and complex. The situation becomes even worse when researchers need to collect data based on field measurements.

Another concern is the accuracy of data. For the greatest accuracy of data, various data-collection methods should be applied in parallel. Although effective sometimes, remote sensing cannot be used as the only method for collecting climate change-related data on the landscape studied. In some cases, direct observation and field measurements should be a complimentary tool. Data collection is important and crucial in that landscape simulation and making assumptions will be based on the dataset collected using different methods, from different sources. Morley et al. (2012) listed a number of challenges while collecting data, including data access, time for assembly, and poor data quality. In addition, providing a rich set of correct data opens the opportunity for landscape depiction in, for example, restoration and rehabilitation projects in the long run. Biogeoclimatic maps (see Bell, 1999) including all historical land-cover and land-use types, are essential for understanding the past conditions of the landscape and its ecological requirements. Such maps contain a wide range of spatial data about the landscape and provide a reliable basis for comparison and analysis of the landscape in the past, present and future.

\subsubsection{Making assumptions}

Mouat et al. (2006) state that alternative futures and scenario analysis in landscape planning is a forum for the exchange of concerns, issues and hopes for the future. The content of the assumptions is the rules under which landscapes change over time. Landscape transformation should be logically formulated and coded to achieve a set of landscape-change rules. Rules depend strongly on a broad range of variables that can be classified into abiotic, biotic and cultural resources (see Botequilha Leitão, 2006). On the one hand, the inherent complexity of natural ecosystems and, on the other hand, the diversity and uncertainty of anthropogenic activities in landscapes provide complicated conditions for making justifiable and plausible assumptions. If researchers pay more attention to climate-change impacts, making assumptions becomes more complicated due to the emergence of new variables and uncertainties. Although it is a fashionable term, climate change is not yet a concern among local authorities. It is also not a widely understood phenomenon among laypeople. Therefore, without pre-educational programs, it is unlikely that justifiable and plausible assumptions will be made for climate changerelated alternatives.

Running an alternative landscape futures project requires two sets of assumptions (Figure 1). To start with, a set of general assumptions are made for all scenarios based on the overall conditions of the landscape studied, and then specific assumptions should be made for each specific alternative according to specific conditions. Making specific assumptions is a major task because it involves various types of knowledge.

Reaching a comprehensive agreement is indispensable for making justifiable and plausible assumptions, and this in turn can build a positive consensus around decision-making issues. Such consensus is a robust basis for the following steps of the process. To ensure the greatest possible accuracy of assumptions, it is essential to pay attention to concepts such as collective wisdom, synergy and strategic thinking.

To reach a comprehensive consensus on assumptions, various methods should be applied due to various stakeholders involved (Figure 2). Conducting a semi-structured informative interview with local authorities, experts and influential people, 


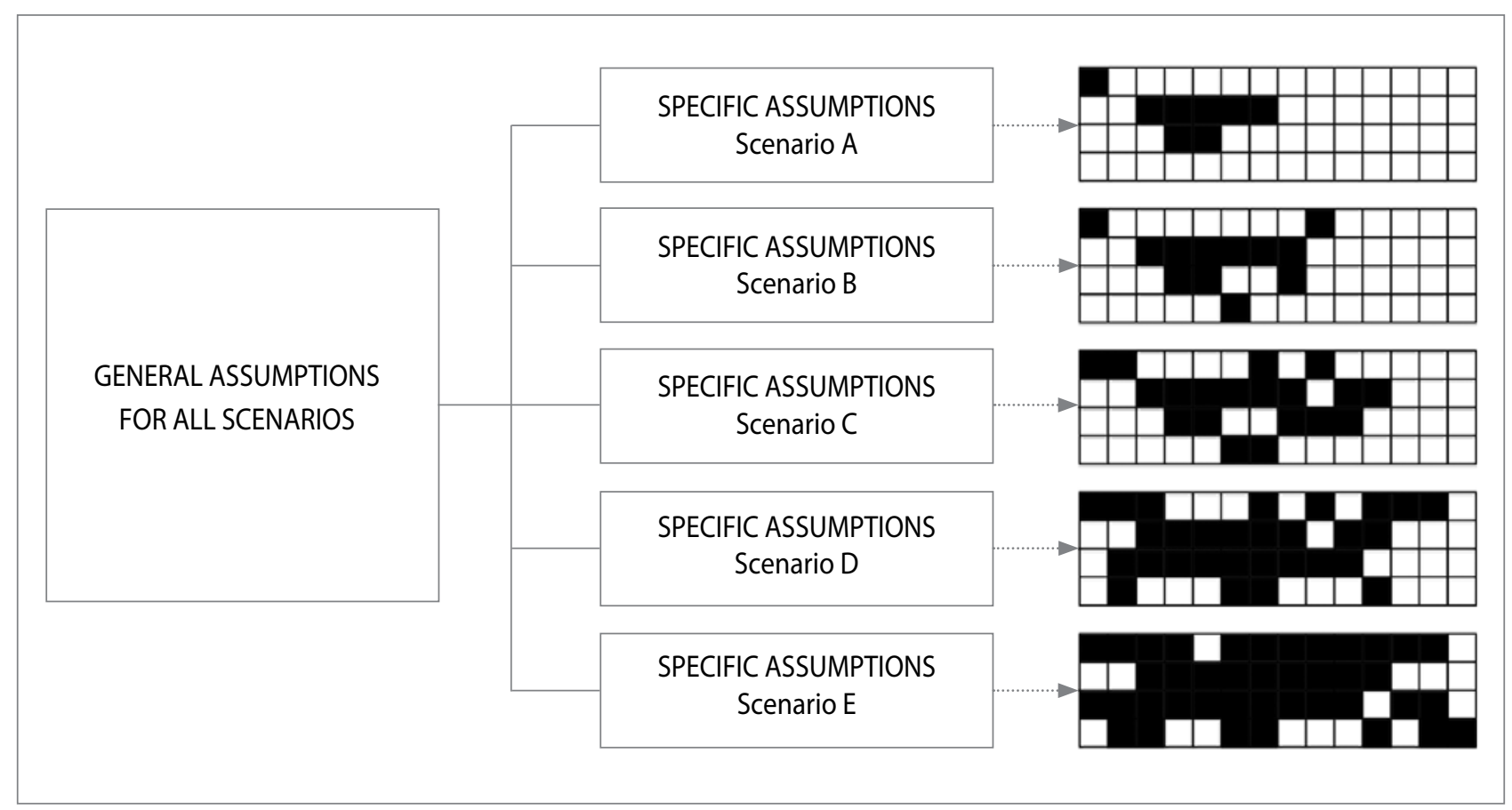

Figure 1: Making general and specific assumptions for constructing alternative futures.

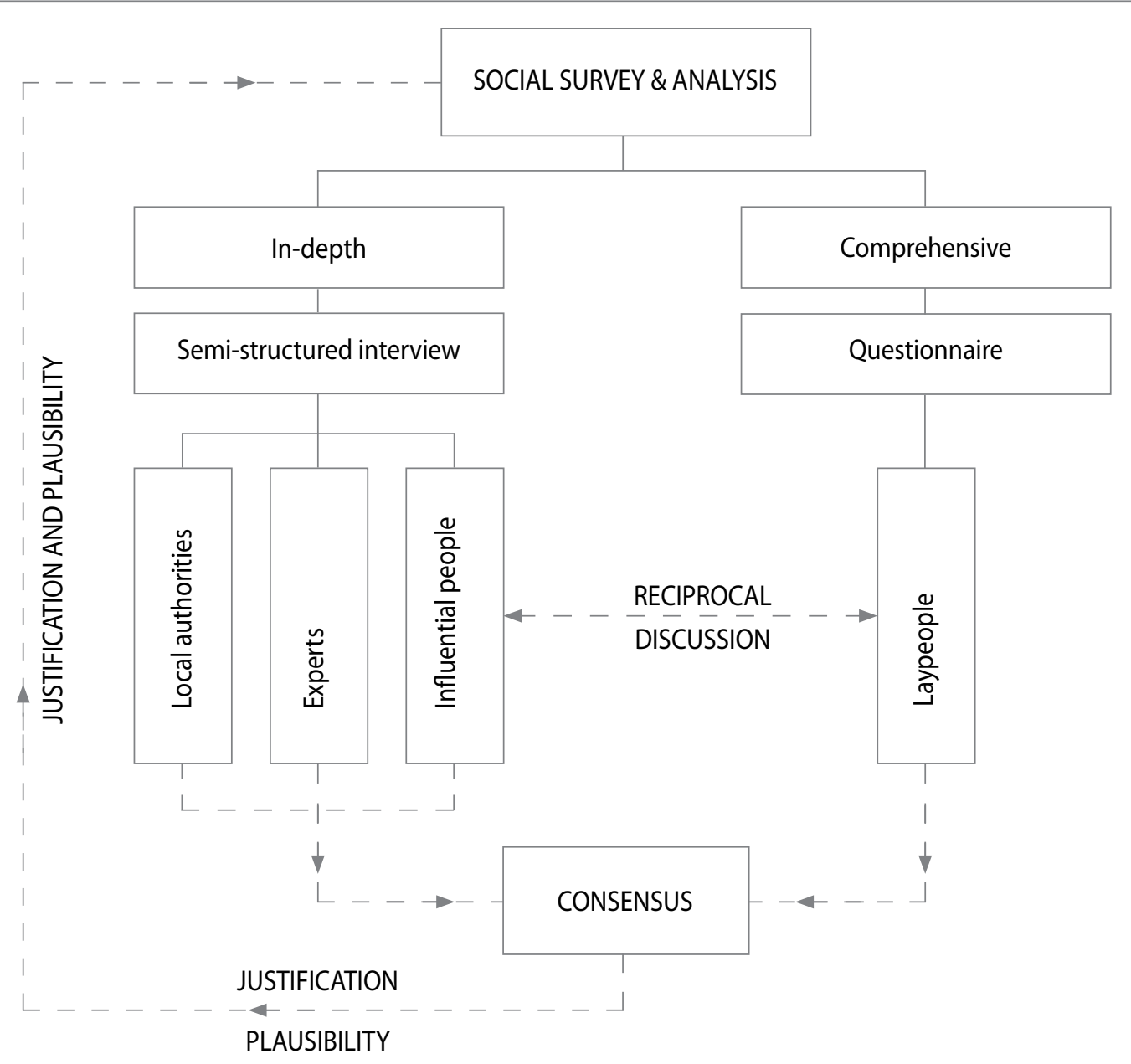

Figure 2: A proposed model for reaching a comprehensive consensus on assumptions due to various stakeholders involved. 


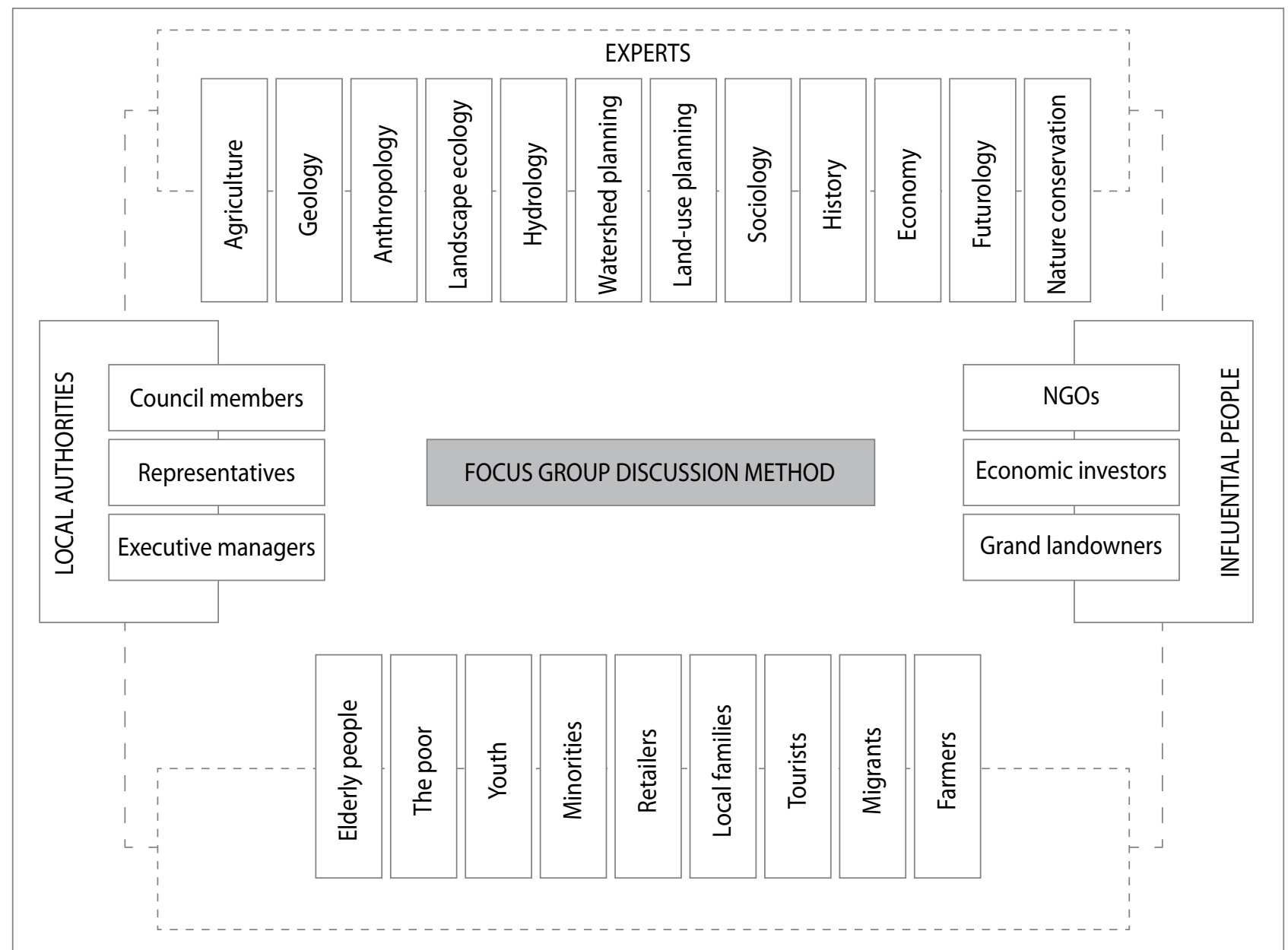

Figure 3: A proposed model for launching focus group discussion among experts, influential people, local authorities and laypeople.

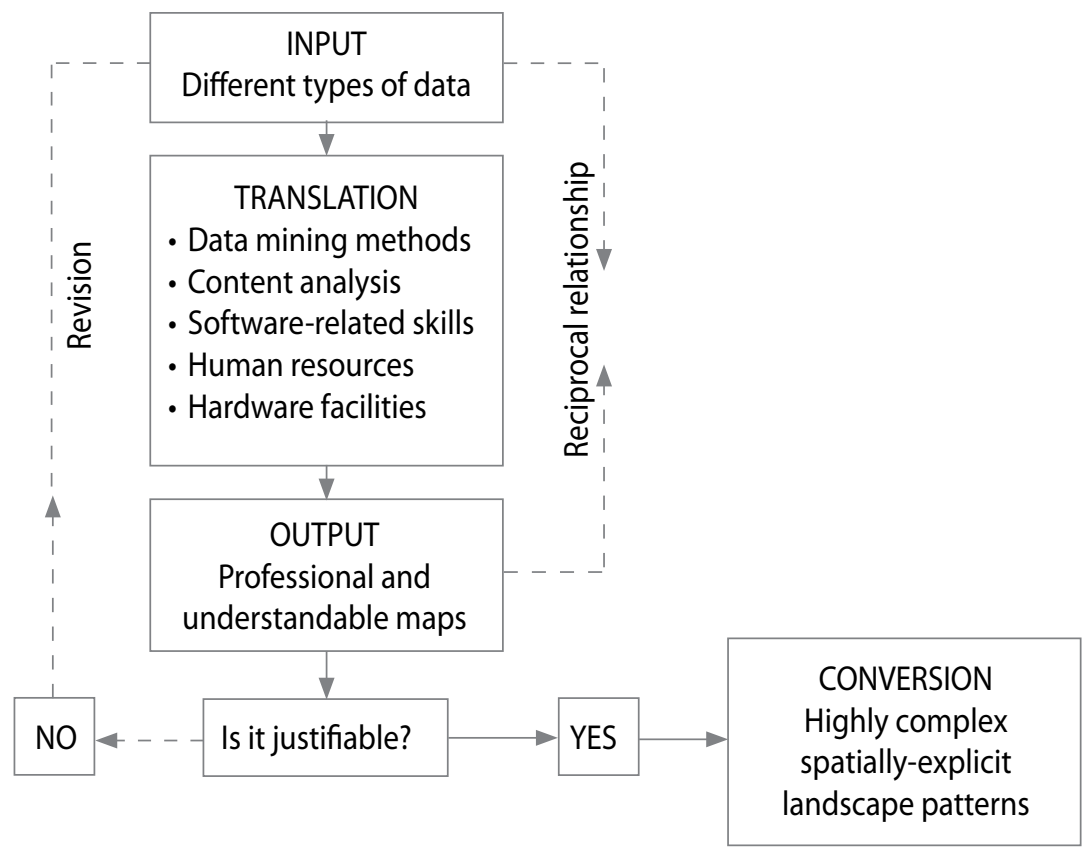

Figure 4: A simplified process of translating verbal, environmental and written data into spatially explicit landscape patterns based on assumptions. 


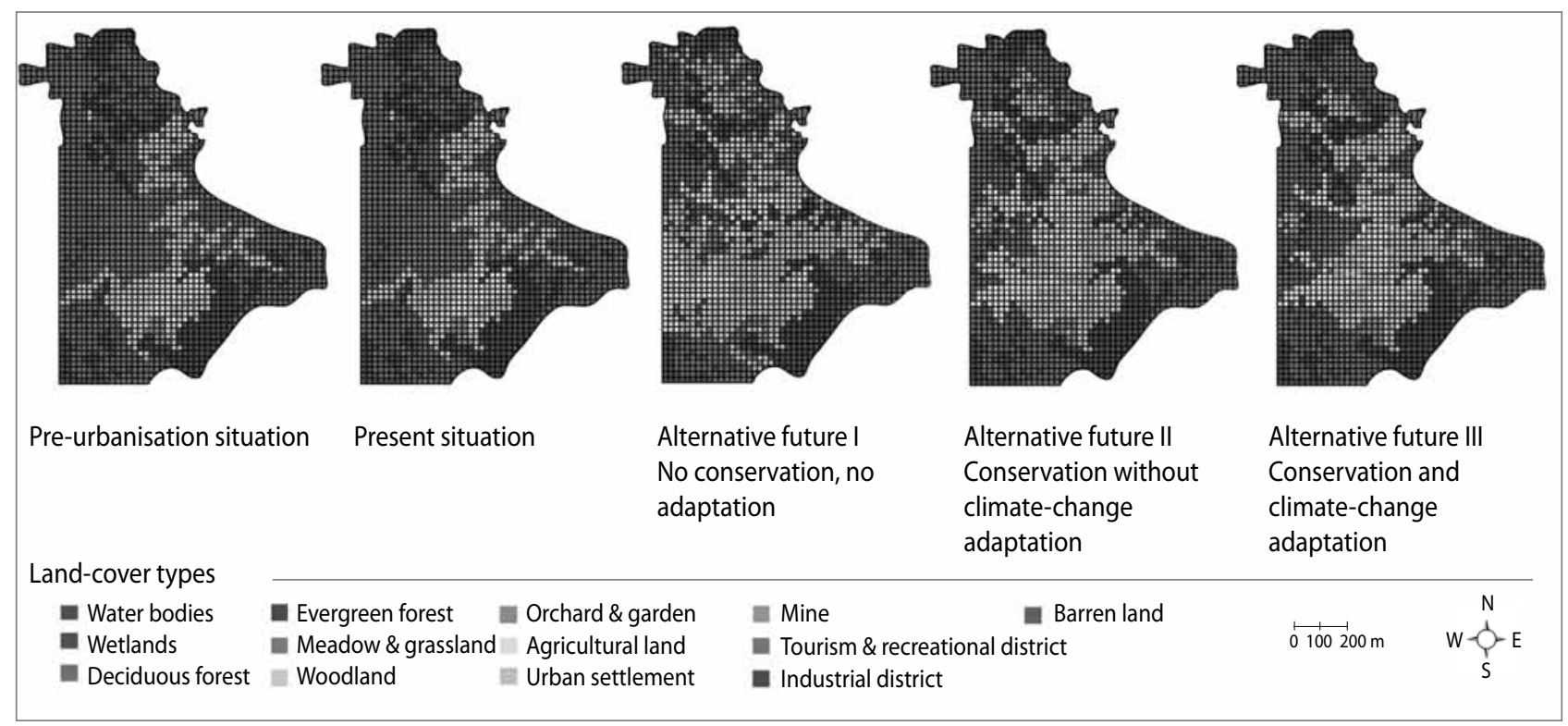

Figure 5: A normal depiction of the present and pre-urbanisation situations as well as three alternatives consisting of "no conservation no adaptation", "conservation without climate change adaptation" and "conservation and climate change adaptation" in a simulated landscape.

as well as a questionnaire-centred survey of laypeople, is important for collecting the attitudes, needs, demands, expectations and goals of the social groups related to the landscape and its likely change over time. To increase the validity in an interview-centred survey and decrease survey error, a snowballing approach is strongly recommended to create a conceptual link among experts, local authorities and influential people, and especially to avoid potential omissions among these groups of interviewees. Based on previous experience (see Hulse et al., 2004), it is also common for local people to elect representatives to regularly engage in discussion sessions during the project.

The significance of focus group discussion has been approved in social studies (see Wilson, 1997). This method is the key to increasing the public participation rate. Although it is timeconsuming and sometimes complicated, focus group discussion is a strong method for linking laypeople to experts, local authorities and influential people (Figure 3). In addition, it is applied to derive hidden/latent problems and desires from in-depth interviews and group discussion through a series of sessions. The output of such sessions is a wide array of causeand-effect diagrams and suggestions that can be used to make assumptions. In a more intellectual manner, holding workshops with experts is another way to construct logical goals and make assumptions for alternatives (see Nassauer \& Corry, 2004). Beyond these, referring to well-established sources is indispensable, especially when making specific assumptions. In ecologically based landscape planning, for example, the four indispensable spatial patterns introduced by Richard Forman (1995), the illustrative patterns presented by Wenche
Dramstad et al. (1996), Lauri Karvonen's guidelines for ecological landscape planning (Karvonen, 2000), the specific guidelines offered by Virginia Dale et al. (2001), and The Environmental Law Institute's conservation thresholds for land-use planners (Environmental Law Institute, 2003) are examples of scientifically based sources through which assumptions can be formulated for ecologically based alternatives (see Penteado, 2013).

\subsection{Depiction}

The necessity of applying spatially explicit landscape modelling has been delineated and proved (Costanza \& Voinov, 2004). Depicting assumptions made in the second step of the process inevitably depends on such models. Translating verbal data including local knowledge, people's attitudes, needs, demands, expectations and goals relating to the landscape - into spatially explicit landscape patterns plays a pivotal role in the effectiveness and success of decision-making in which alternative futures and scenario analysis is the main tool. Using appropriate software and choosing appropriate models is essential (see Cartwright, 2008; Pettit \& Wyatt, 2009). This step of the process is highly important because translating assumptions in the form of sets of words and phrases into digital maps is an integral part of defining different trajectories and, consequently, depicting different futures. The level of accuracy and validity of spatially explicit landscape patterns greatly depends on the accuracy and quality of this translation. Researchers, as translators, should be highly qualified and trained in order to ensure that assumptions are translated correctly. This conversion, in itself, reflects stakeholders' attitudes and goals relat- 


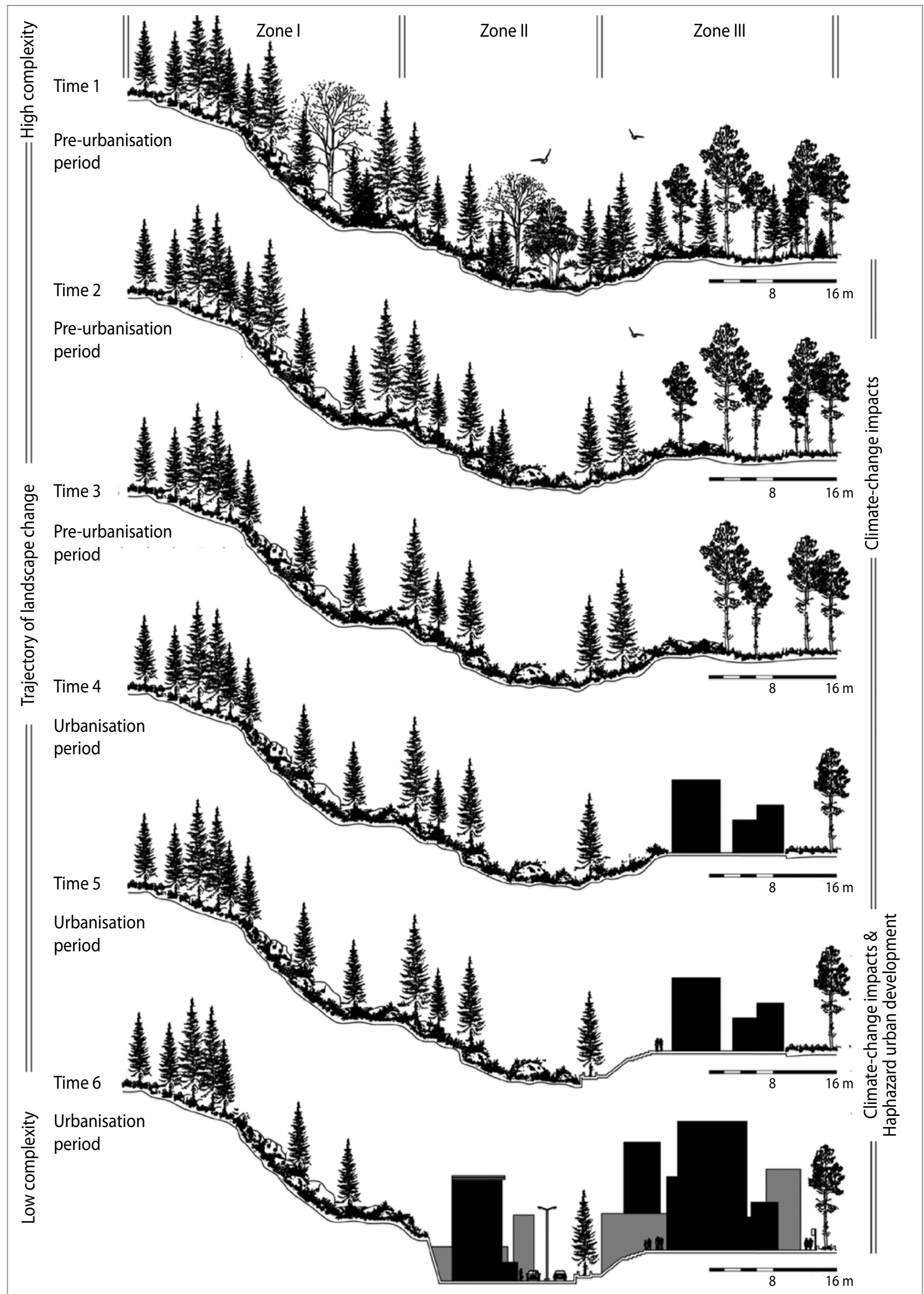

Figure 6: Depicting the trajectory of change due to climate change impacts ( $T_{1}$ to $T_{3}$ ) and both haphazard urban development and climate change impacts $\left(\mathrm{T}_{4}\right.$ to $\left.\mathrm{T}_{6}\right)$ in a spatially explicit landscape simulation, from high landscape complexity to low landscape complexity. 
Table 2: Four general steps in applying alternative futures and scenario analysis in landscape planning for climate change

\begin{tabular}{|c|c|c|}
\hline General steps & Sub-steps & Requirements and issues under investigation \\
\hline \multirow{4}{*}{ Definition } & & Verbal data: stakeholders' attitudes, needs, demands, expectations and goals. \\
\hline & Data collection & $\begin{array}{l}\text { Environmental data: abiotic, biotic and cultural resources, land-cover changes, geo-hydrological } \\
\text { dynamics, soil structures, wildlife dispersal patterns, human-built development, urban and rural } \\
\text { growth patterns and demographic trends over time. }\end{array}$ \\
\hline & & $\begin{array}{l}\text { General assumptions: a set of general rules that is defined for all alternative landscape futures } \\
\text { to define the trajectory of landscape change over time. }\end{array}$ \\
\hline & Making assumptions & $\begin{array}{l}\text { Specific assumptions: a set of specific rules that is defined for each alternative landscape future } \\
\text { specifically to define the trajectory of landscape change under particular circumstances over } \\
\text { time. }\end{array}$ \\
\hline \multirow{4}{*}{ Depiction } & & Basic definitions: scale, resolution, land-cover classification in map legend. \\
\hline & & $\begin{array}{l}\text { Software and hardware requirements: possibility of using software such as Arc GIS, FRAGSTATS, } \\
\text { 3-D Studio Max, Cry Engine and Esri City Engine. }\end{array}$ \\
\hline & & $\begin{array}{l}\text { Human resources: availability of collaboration with highly qualified researchers for translating } \\
\text { assumptions into spatially explicit landscape patterns. }\end{array}$ \\
\hline & & $\begin{array}{l}\text { Consensus mechanism: a justifiable mechanism to guarantee the interactions between resear- } \\
\text { chers, policymakers and stakeholders in translation. }\end{array}$ \\
\hline \multirow{3}{*}{ Evaluation } & & $\begin{array}{l}\text { Defining indicators and metrics: a set of qualitative and quantitative indicators and landscape } \\
\text { metrics to systematically analyse each alternative landscape future. }\end{array}$ \\
\hline & & $\begin{array}{l}\text { Analysers: a group of highly qualified experts that participate in a team to describe alternative } \\
\text { landscape futures and explore their advantages and disadvantages. }\end{array}$ \\
\hline & & $\begin{array}{l}\text { Multi-criteria decision-making techniques: the possibility of applying quantitative methods } \\
\text { such as SAW (simple additive weighted), TOPSIS (technique for order preference by similarity to } \\
\text { ideal solution) and ELECTRE (elimination and choice expressing reality) and combine them with } \\
\text { qualitative methods such as a Delphi panel. }\end{array}$ \\
\hline \multirow[t]{2}{*}{ Synthesis } & & $\begin{array}{l}\text { Trade-offs: ranking alternative landscape futures based on socioeconomic, cultural, ecological } \\
\text { and environmental priorities. }\end{array}$ \\
\hline & & Selection: choosing the most justifiable alternative landscape futures. \\
\hline
\end{tabular}

ing to the landscape's future. Since 2000, three-dimensional depictions of alternative futures have become a commonplace method to enhance the level of laypeople's perception regarding spatial and temporal concepts (e.g., Hulse et al., 2004; Nassauer \& Corry, 2004; Berger \& Brown, 2008; Mansergh et al., 2008). In addition, using new techniques such as cellular automata (CA) in running scenarios is crucial (see Maxwell et al., 2004; Clarke, 2008; Liu, 2009). In the survey, most participants agreed that translating data into spatially explicit landscape patterns is still a challenging issue in alternative futures-based landscape-planning projects. According to the survey, about $90 \%$ of participants "strongly agree" or "agree" with this view. Having analysed a considerable number of case studies around the world, a simple and important model can be proposed for translating non-spatial data into spatially explicit landscape patterns (Figure 4). The model illustrates how different types of data can be converted to useful spatially explicit landscape patterns after a long process. Ultimately, the outputs should be illustrations that can be easily understood (Figure 5 and Figure 6).

\subsection{Evaluation and synthesis}

Despite all advancements, evaluating alternatives still faces a wide range of limitations (Corry \& Nassauer, 2005). In general, a group of highly experienced experts should be engaged in the evaluation to analyse alternatives based on the criteria selected. To do so, quantitative methods, including multiple attribute/criteria decision-making approaches such as SAW (simple additive weighting), TOPSIS (Technique for order preference by similarity to ideal solution) and ELECTRE (elimination and choice expressing reality), and qualitative methods such as a Delphi panel would be beneficial as well as appropriate (see Hwang \& Yoon, 1981; Pimerol \& Romero, 2000; Linstone \& Turoff, 2002). In this step, the most difficult task is to find a shared language between experts from different disciplines to evaluate alternatives and scenarios. Arc GIS can be a sufficient tool to facilitate this communication.

In evaluation, landscape metrics relating to climate change should be defined. Both climate change and anthropogenic 


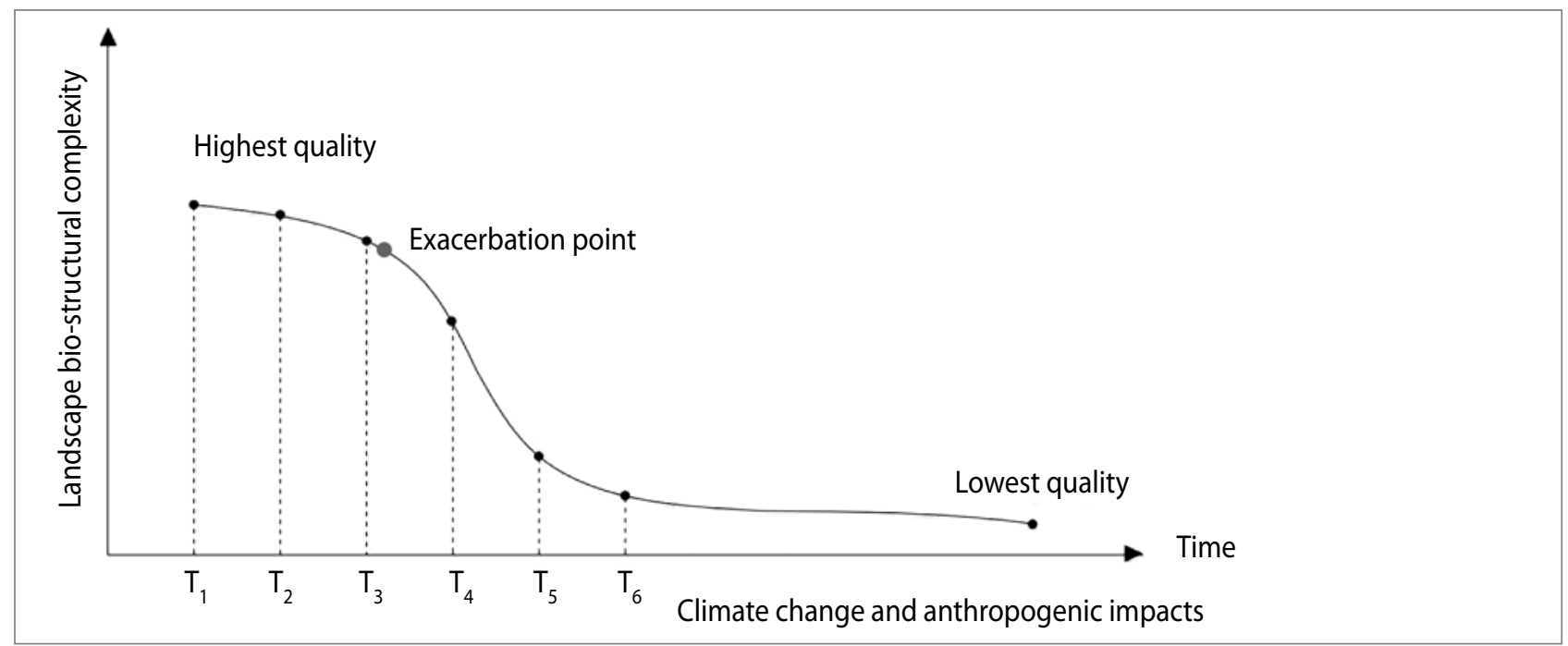

Figure 7: Trajectory of bio-structural landscape change with reference to the change in the quality of life over time from the pre-urbanisation period $\left(T_{1}\right.$ to $\left.T_{3}\right)$ to the urbanisation period (starting from the exacerbation point).

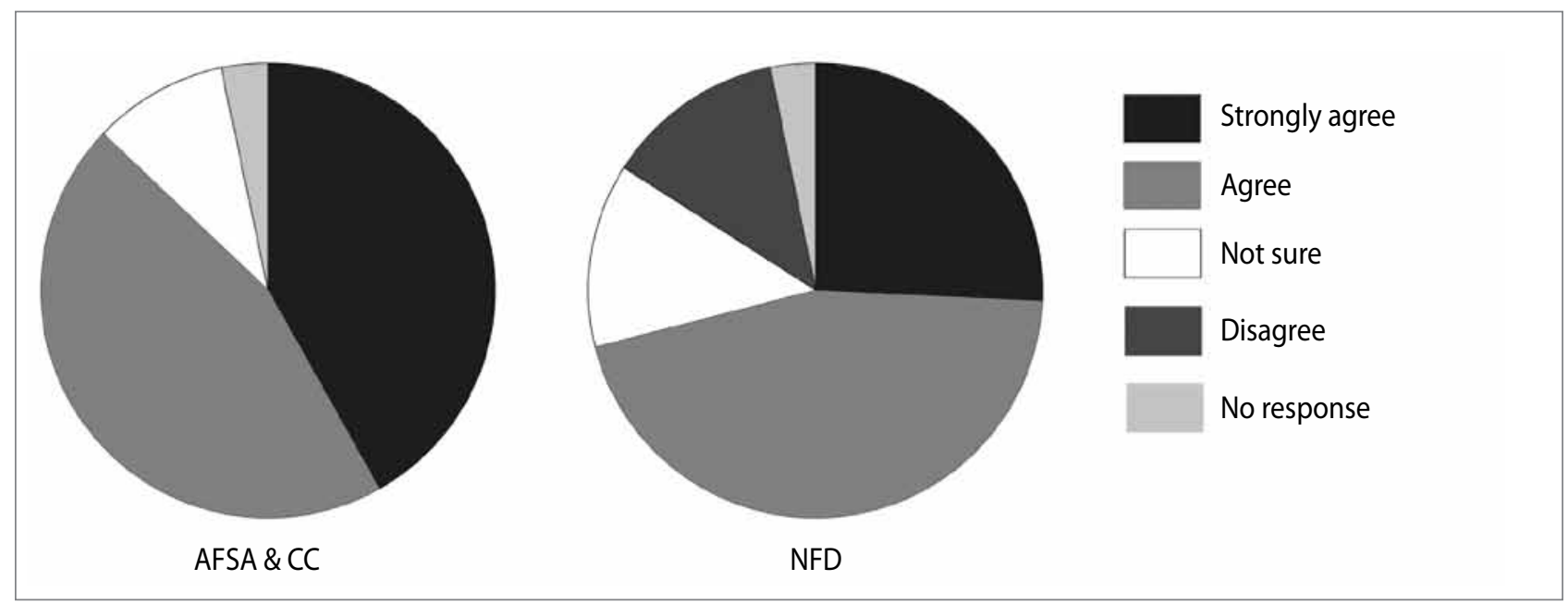

Figure 8: a) The role of alternative futures and scenario analysis in climate-change mitigation and adaptation; b) and the need for the approach development over the coming decades.

Note: a) AFSA \& CC: "strongly agree" = 42\%, "agree" = 45\%, "not sure" = 10\%, "no response" = 3\%; b) NFD: "strongly agree" = 26\%, "agree" = 45\%, "not sure" $=13 \%$, "disagree" $=13 \%$, "no response" $=3 \%$

impacts can be addressed by quantitative methods. New metrics from a careful combination of common metrics can be taken into consideration. Landscape bio-structural complexity, for example, is a suggested metric that can be examined as a basis for comparing landscape change over an extended period of time during evaluation and synthesis (Figure 7). In this instance, a set of landscape composition and configuration metrics can be merged to define a more powerful metric for evaluation.

\subsection{Perspectives, challenges and gaps}

In general, there is a robust consensus among experts regarding the effectiveness of alternative futures and scenario analysis as a decision-making approach in landscape planning. Ac- cording to the survey results, approximately $74 \%$ and $23 \%$ of participants strongly agree and agree with this viewpoint. No disagreement was recorded in the responses. This result proves that using alternative futures is a valid tool for envisioning the landscape future across the world. These numbers show that participants have a united voice in the inevitable role of this approach regarding landscape-planning issues. An increase in the use of this approach in landscape-related decision-making in various countries is also confirmed by the results of the survey. The results indicate that this approach can also be a way to develop knowledge of landscape ecology in applied landscape-planning projects. According to the survey, about $90 \%$ of participants strongly agree, or at least agree, that using alternative futures and scenario analysis in landscape planning can contribute to an awareness relating to landscape ecology 
knowledge and vice versa. The surprising finding is that no disagreement was documented among respondents in this case.

Furthermore, the responses to the survey show that this approach can be used more widely in the twenty-first century. It has been argued that this approach is clearly a horizontal tool of landscape planning for different purposes. The vast majority of participants (about 87\%) feel that alternative futures and scenario analysis can be an effective approach for addressing climate change through depicting spatially explicit landscape patterns and climate change-induced spatial changes over time. About $71 \%$ of respondents believe that this approach is still in its initial stages and should be developed during the coming decades (Figure 8). This finding indicates that there is special attention to climate change among researchers working on alternative landscape futures. Despite this, some statement reflected a degree of scepticism about the role of this approach as a tool for making decisions about landscapes through depicting climate-change mitigation strategies. For example, one participant stated:

At this time, I doubt that alternative futures can be a useful tool for climate change mitigation. There is too much uncertainty about how the climate will change and more even uncertainty about how ecosystems will respond to climate change. If climate change and ecosystem models greatly improve such that uncertainty is greatly reduced, then it may make sense to incorporate them into an alternative futures process.

Nonetheless, there is still a divergence of opinions around some issues. For example, in the case of practical aspects, there is no agreement on the exact number of alternatives that should be defined in a given landscape-planning project. Whereas $16 \%$, $13 \%, 10 \%$ and $19 \%$ of respondents stated that the number of alternatives should be three, four, five or more than five, about $29 \%$ of them believe that it cannot be determined. In addition, three respondents are convinced that the number of alternatives should be between three and five, and only one participant left the question unanswered.

Despite all advancements and achievements in applying this approach in making decisions and landscape planning, there are still challenges and problems in practice that should be addressed. To diagnose the most challenging steps of the approach in applied activity, numerous projects were examined (e.g., Theobold \& Hobbs, 2002; Hunter et al., 2003; Steinitz et al., 2003; Aycrigg et al., 2004; Berger \& Bolte, 2004; Hulse et al., 2004; Nassauer \& Corry, 2004; Schumaker et al., 2004; Sharma et al., 2005; Bryan et al., 2008; Patel et al., 2007; Kepner et al., 2008; Soliva et al., 2008; Hulse et al., 2009; Verburg et al., 2010; Oana et al., 2011; Morley et al., 2012). Respondents were then asked to state the challenges and dif-

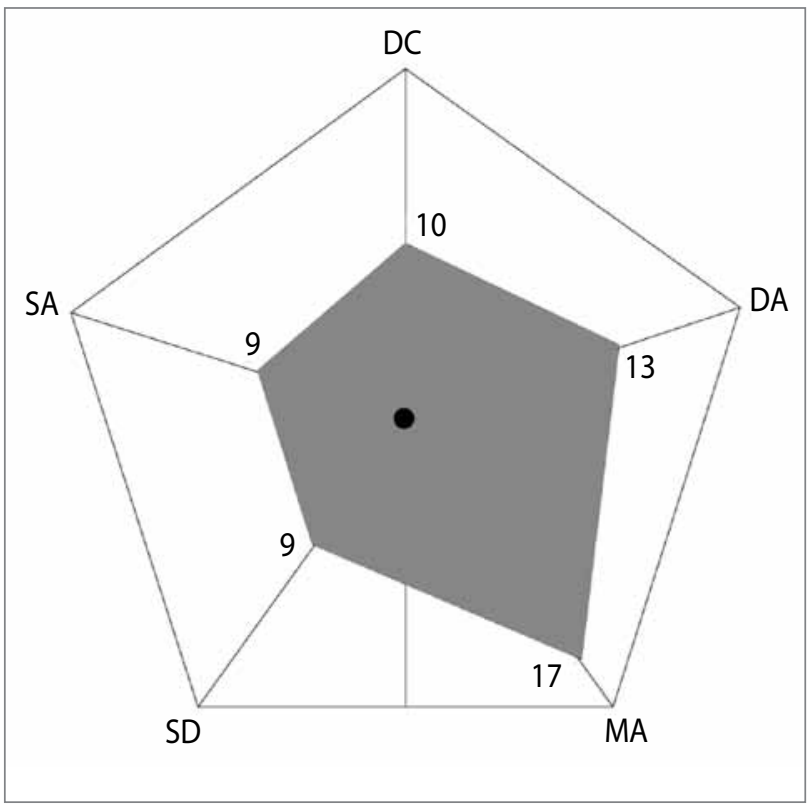

Figure 9: Five major steps in applying alternative futures and scenario analysis in landscape planning: data collection (DC), definition of alternatives (DA), making assumptions (MA), simulation and depiction of scenarios (SD) and scenario analysis (SA). The degree of being challengeable in practice was identified based on the number of selections by the participants.

ficulties that they encountered. According to the survey results, the factor "making assumptions" (MA) was selected seventeen times by respondents as the most challenging step of the approach. After that, "definition of alternatives" (DA) based on the project requirements, goals and research questions was identified as the second most challenging step. Next, "data collection" (DC) was selected ten times by the respondents. These three steps are defined in "definition", the first step of the mechanism, and this reemphasises the fact that the first step of such projects is highly important. According to the results, "simulation and depiction of scenarios" (SD) and "scenario analysis" (SA) were seen as less challenging (Figure 9). In some cases, participants also provided additional information in their responses. For example, one expert stated that all steps are important, but data collection and collecting historical landscape records is a requisite for the following steps:

... I picked the first one [data collection and collecting historical landscape record], for the reason that if you fail in that you will fail in all the next phases as well. If collecting historical data based on non-spatial data, for example interviewing people, results can be good in the best case but often people do not remember things accurately in terms of time and place, and stories of different people can be different. If collecting spatial data, e.g. historical maps, the mapping process and its purpose has to be known as those maps differ greatly from the present ones. In our project, for example, we used historical parceling maps which aimed at distributing goodproductive and bad-productive agricultural land evenly between 
Table 3: The most important statements derived from open-ended questions regarding the appropriate scale in alternative futures and scenario analysis.

\begin{tabular}{|c|c|c|}
\hline Attitudes & Variables mentioned & Examples of the most important statements \\
\hline \multirow{14}{*}{ No specific scale } & \multirow[t]{2}{*}{$\begin{array}{l}\text { Nature of problem, } \\
\text { nature of participants }\end{array}$} & $\begin{array}{l}\text { This strongly depends on the nature of the problem and the nature of the participants. } \\
\text { However, it should not be too small (i.e., smaller than around } 10 \times 10 \mathrm{~km}^{2} \text { ) or too lar- } \\
\text { ge (i.e., larger than } 100 \times 100 \mathrm{~km}^{2} \text { ). Note that scenarios can be developed for regions } \\
\text { that are much larger (up to global), but the planning needs to be for smaller areas. }\end{array}$ \\
\hline & & $\begin{array}{l}\text { This depends on who needs this information. However, given the current level of un- } \\
\text { derstanding and the uncertainty associated with climate change projections, there is } \\
\text { little genuine value in considering areas that are less than } 105 \text { ha. }\end{array}$ \\
\hline & \multirow{4}{*}{$\begin{array}{l}\text { Research question, lan- } \\
\text { dscape type }\end{array}$} & It depends on the research question and the type of landscape. \\
\hline & & The size of the area depends on the questions about landscape change being asked. \\
\hline & & It depends on the research question and the type of landscape. \\
\hline & & $\begin{array}{l}\text { The alternative futures can pertain to the entire study area or only a portion of it, de- } \\
\text { pending on the variable. }\end{array}$ \\
\hline & \multirow{5}{*}{$\begin{array}{l}\text { Aim of project, landscape } \\
\text { characteristics }\end{array}$} & It depends on the aims of the project, on the landscape characteristics and extension. \\
\hline & & $\begin{array}{l}\text { It depends on the scope of the project (regional, sub-regional, catchment, landscape } \\
\text { matrix) and its context. }\end{array}$ \\
\hline & & It depends on the study area. \\
\hline & & It might vary according to the fragmentation of the area. \\
\hline & & It depends on the city: the entire urban area should be included. \\
\hline & Data availability & $\begin{array}{l}\text { As the spatial extent of analysis becomes smaller, the spatial grain of data must beco- } \\
\text { me finer and both the data and models must be more accurate. }\end{array}$ \\
\hline & \multirow{2}{*}{ Resolution } & I prefer as large as possible. Resolution is important. \\
\hline & & It depends on land cover data available down to 30 by $30 \mathrm{~m}^{2}$. \\
\hline \multirow{2}{*}{\multicolumn{2}{|c|}{ Specific scale determined }} & $A>100 \mathrm{~km}^{2} ; A>1000 \mathrm{~km}^{2} ; 1 \leq A \leq 100 \mathrm{~km}^{2} ; 10 \leq A \leq 100 \mathrm{~km}^{2}$ \\
\hline & & $100 \leq \mathrm{A} \leq 10,000 \mathrm{~km}^{2} ; 5,000 \leq \mathrm{A} \leq 50,000 \mathrm{~km}^{2}$. \\
\hline \multirow{3}{*}{ Other responses } & & At least three scales are needed. \\
\hline & & Could be at any scale: site to global. \\
\hline & & The scale is less significant than taking the area and issue as a whole. \\
\hline
\end{tabular}

Table 4: Dependency of the approach on eight qualitative factors affecting the approach implementation in landscape-planning projects.

\begin{tabular}{|c|c|c|c|c|c|c|c|}
\hline \multirow[t]{2}{*}{ Factors } & \multicolumn{7}{|c|}{ Likert scale (\%) weighted from 5 to 1} \\
\hline & $\begin{array}{l}\text { Strongly agree (\%) } \\
\mathrm{w}=5\end{array}$ & $\begin{array}{l}\text { Agree (\%) } \\
w=4\end{array}$ & $\begin{array}{l}\text { Not sure (\%) } \\
\mathrm{w}=3\end{array}$ & $\begin{array}{l}\text { Disagree (\%) } \\
\mathrm{w}=2\end{array}$ & $\begin{array}{l}\text { Strongly disagree (\%) } \\
\mathrm{w}=1\end{array}$ & $\begin{array}{l}\text { No response (\%) } \\
\mathrm{w}=0\end{array}$ & $\begin{array}{l}\text { Total score } \\
\left(\Sigma \mathrm{S}_{\mathrm{i}} \times \mathrm{W}_{\mathrm{i}}\right) \\
\end{array}$ \\
\hline LPP & 36 & 45 & 19 & 0 & 0 & 0 & 417 \\
\hline LEK & 32 & 42 & 16 & 10 & 0 & 0 & 396 \\
\hline SRF & 26 & 42 & 19 & 10 & 0 & 3 & 375 \\
\hline SCM & 6 & 52 & 26 & 13 & 3 & 0 & 345 \\
\hline MA & 61 & 26 & 10 & 3 & 0 & 0 & 445 \\
\hline LCT & 7 & 23 & 45 & 16 & 3 & 6 & 297 \\
\hline QHR & 36 & 61 & 3 & 0 & 0 & 0 & 433 \\
\hline MMT & 26 & 29 & 19 & 23 & 0 & 3 & 349 \\
\hline Average $(\sim)$ & 28.6 & 40 & 19.5 & 9.2 & 0.6 & 2.1 & 389 \\
\hline
\end{tabular}




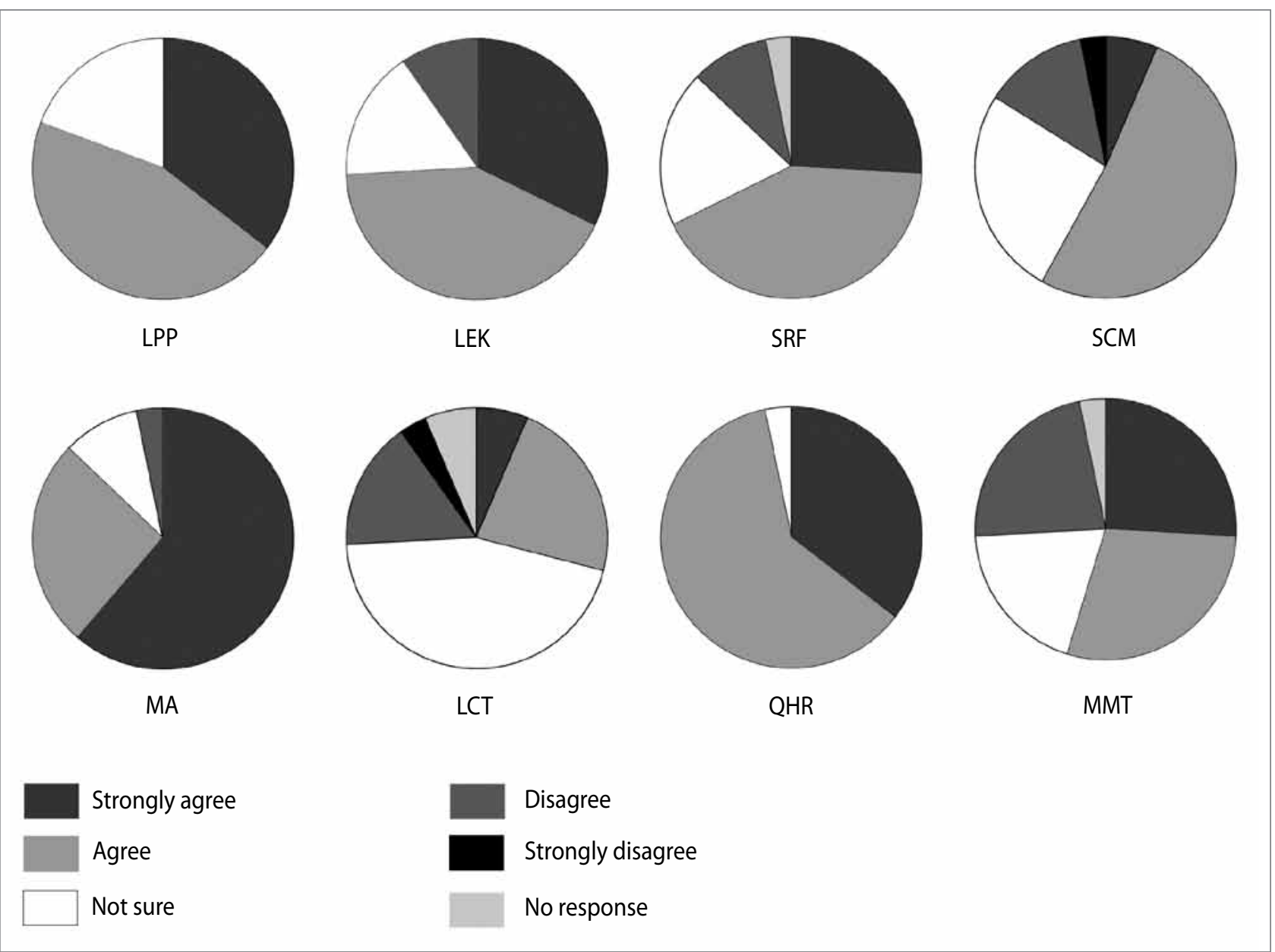

Figure 10: Dependency of the approach on eight qualitative factors affecting the approach implementation in landscape-planning projects. Note: LPP = Local people participation, LEK = Local ecological knowledge, SRF = Software-related facilities, SCM = Statistical concepts and methods, MA = Making assumptions, LCT = Land-cover types, QHR = Qualified human resources, MMT= Modelling methods and tools.

the different households. To be able to interpret those maps, you have to initially understand that all the map categories are based on land productivity, and only those good-productive plots have been mapped in high accuracy...

Another important challenge reflected in the completed questionnaires is choosing the appropriate scale and resolution. Many participants believe that the scale of study should be spatially broad, but there is no consensus regarding the exact scale for applying alternative futures and scenario analysis in landscape planning. Analysis of case studies reveals that the issue of scale varies from individual site to global, as shown by the survey results (Table 3). Although there seem to be similarities in applying logical criteria for choosing appropriate scale and resolution, some researchers prefer to choose different scales in different situations. One of the most important reasons is the lack of accessibility to accurate spatial data, including updated satellite images and aerial photos. Although some respondents specified a particular scale and resolution, the majority of respondents cited no specific standard for choosing scale and resolution. The latter group mentioned diverse variables that shaped their responses. The responses reflect that the scale should be selected case by case, according to the study goals and objectives.

Beyond these controversial issues, there are deeper challenges and gaps that should be investigated for further development of the approach in the future. According to the responses, some practical challenges deserve more attention. One participant stated:

... the biggest challenge is actually getting the planners and decisionmakers to use the information and outputs that are generated by scenario analyses...

Applying alternative futures and scenario analysis depends on a broad spectrum of requirements and prerequisites ranging from human resources to technological tools. In many cases, failure in applying this approach has been the result of shortcomings and weaknesses in these requirements and prerequisites. Using 
Table 5: Information excerpts depicting the current concerns and challenges in applying alternative futures and scenario analysis in landscape planning

\begin{tabular}{ll}
\hline Category & Current concerns and challenges \\
\hline Scale and size & $\begin{array}{l}\text { Lack of appropriate scale and resolution due to the absence of effective technological infrastruc- } \\
\text { tures and tools. } \\
\text { Lack of accurate land-based data. }\end{array}$ \\
\hline $\begin{array}{l}\text { Consensus building on definition of } \\
\text { alternatives }\end{array}$ & $\begin{array}{l}\text { experts, and researchers. } \\
\text { Divergence of objectives relating to landscape due to deep differences in stakeholders' cultural, } \\
\text { economic, and social backgrounds. }\end{array}$ \\
& $\begin{array}{l}\text { Difficulty of providing a long-term platform for people and their representatives to be engaged } \\
\text { in building consensus on defining alternatives. }\end{array}$ \\
\hline Lack of historical data regarding the landscape under study and investigation. \\
Being time-consuming, especially in making specific assumptions for each specific alternative. \\
Discernible differences between people's visions about landscape future. \\
Uncertainties about the future. \\
Lack of sufficient confidence in the future. \\
\hline $\begin{array}{l}\text { Complexity of translating words, phrases, texts, sketches, flowcharts, and diagrams into spatially } \\
\text { explicit landscape patterns. } \\
\text { Dearth of simulation and spatial modelling skills. }\end{array}$ \\
$\begin{array}{l}\text { Complexity of selecting appropriate qualitative and quantitative indicators for making compari- } \\
\text { son between alternatives. } \\
\text { Difficulty of overlapping evaluations provided by each group of experts. }\end{array}$ \\
\hline
\end{tabular}

multiple-choice questions based on a Likert scale, the approach depends on eight factors: local people participation (LPP), local ecological knowledge (LEK), software-related facilities (SRF), statistical concepts and methods (SCM), making assumptions (MA), land-cover types (LCT), qualified human resources (QHR), and modelling methods and tools (MMT). The results show that making assumptions (MA) and qualified human resources (QHR) are the most important factors in applying alternative futures and scenario analysis in landscape planning affecting the quality and accuracy of the project. Next, local people participation (LPP), local ecological knowledge (LEK), software-related facilities (SRF), modelling methods and tools (MMT), statistical concepts and methods (SCM) and ultimately the number of land-cover types (LCT) stand in the next places. Weighted numbers and scores were calculated to form a meaningful statistical picture of the value and importance of each factor (Table 4 and Figure 10).

It is clear that the use of alternative futures and scenario analysis in decision-making for landscapes has been recognised. More importantly, there has been progress in the development of this approach that facilitates its application in climate change-related decision-making. Despite this, there are concerns and challenging issues that should be examined. These concerns and challenges have been categorised according to the findings of the literature review as well as the results of the survey (Table 5). Many reasons have been cited by participants for the existence of such problems. The analysis of applied projects, as mentioned above, demonstrates a need to refine, upgrade, develop, and update this approach to make it more applicable under conditions of climate change. These actions should encompass all issues relating to the application of alternative futures from the beginning to the end.

\section{Conclusion}

This study showed that applying alternative futures and scenario analysis in landscape planning can provide a perfect platform for examining the likely effects of adaptation and mitigation strategies on a landscape's future in the face of climate change impacts. The approach opens up a great opportunity for decision-makers to extend their perspective and adopt appropriate landscape policies before reaching a no-return point, from the sustainable point of view. Inappropriate use of this method can be misleading, causing detrimental effects on decision-making and consequently policies adopted for landscapes. In fact, this approach can be a key policy instrument for how to integrate climate change impacts, social values and ecological conditions into decision processes when planning landscapes. Applying this approach can reduce the common conflicts among stake- 
holders whose values and attitudes are completely different. Alternative futures and scenario analysis is a multidimensional mechanism through which informed decisions can be made based on collective wisdom.

Thanks to recent technological advancements, this approach can be effective more than ever before. In the future, for example, satellite images can make collecting historical landscape data easier than in the past. Because software is developing rapidly, landscape simulation is becoming increasingly realistic and understandable, like never before. At the same time, the use of these technological tools is becoming increasingly sophisticated and this in turn requires more trained human resources. While technologies are progressing, landscape datasets should also be updated and enriched. For example, preparing biogeoclimatic landscape maps in each region provides a perfect basis for defining restorative as well as climate changeproof alternatives. When a biogeoclimatic map is available, it becomes possible to formulate a road map for converting current landscape patterns into ecologically restored ones through defining specific alternatives. Familiarity with the natural history of a landscape is another important factor ensuring that restorative and climate change-proof alternatives are defined accurately.

This study shows that there is still an essential need to develop methods and technologies through which justifiable and reliable assumptions can be translated into realistic spatially explicit landscape patterns. In this case, using pictorial questionnaires and illustrative sketches can build up an understanding of climate-change impacts on a landscape's future especially among laypeople. People's participation plays an important role in collecting data and making assumptions. Therefore, it is essential to facilitate people's engagement in these activities through various incentives. Some online facilities (e.g., internet-based social networks) are available options that can be used to push back geographical distances and help researchers tackle some problems relating to public participation. People that live in a landscape can increase the odds of achieving success if they play their role correctly. All beneficiaries should have their own voice in the entire process of making decisions and adopting landscape policies. Justice is the key in this instance. It is society's right to choose its destiny based on active participation and informed decisions. Where people have a sense of attachment to the project, they strive to actively take part in all steps of the project. Local landowners as a potential driving force behind landscape restoration plans can also play a crucial role to guarantee the success of the decisions made based on comprehensive consensus.

To adopt landscape policies with regard to climate change impacts, new types of data should be gathered, new assumptions should be made, new simulation techniques should be applied and new metrics should be defined for evaluating alternatives. Beyond these, landscape ecology, as a trans-disciplinary science, should be taken into consideration when addressing climate change issues because these principles hold the key to defining new alternatives in the initial steps, as well as providing metrics to evaluate them at the end of the project. This research paves the way for examining the potential advantages of this approach in making decisions and adopting policies for a landscape's future, where urbanisation and climate change are two powerful driving forces behind inevitable changes. Furthermore, it invites other researchers to address the current gaps, challenges and perspectives for better use and more effective application of the approach in the future.

\section{Amin Rastandeh}

Tarbiat Modares University, Tehran, Iran

E-mail:amin.rastandeh@yahoo.com

\section{References}

Acharya, A. K. \& Barragán Codina, M. R. (2012) Social segregation of indigenous migrants in Mexico: An overview from Monterrey. Urbani izziv, 23(1), pp. 140-149. DOI: 10.5379/urbani-izziv-en-2012-23-01-006

Ahern, J. (1997) At the crossroads: Sustainable future or urban sprawl? Spatial concepts and scenarios for the Lisbon metropolitan area. In: Reis Machado, J. \& Ahern, J. (eds.) Environmental challenges in an expanding urban world and the role of emerging information technologies, pp. 13-26. Lisbon, CNIG.

Ahern, J. (1999) Spatial concepts, planning strategies and future scenarios: A framework method for integrating landscape ecology and landscape planning. In: Klopatek J. \& Gardner, R. (eds.) Landscape ecological analysis: Issues and applications, pp. 175-201. New York, Springer. DOI: 10.1007/978-1-4612-0529-6_10

Ahern, J. (2007) Green infrastructure for cities: The spatial dimension. In: Novotny, V., Breckenridge, L. \& Brown, P. (eds.) Cities of the future: Towards integrated sustainable water and landscape management, pp. 267-283. London, IWA Publishing.

Alberti, M. \& Marzluff, J. M. (2004) Ecological resilience in urban ecosystems: linking urban patterns to human and ecological functions. Urban Ecosystems, 7(3), pp. 241-265.

DOI: 10.1023/B:UECO.0000044038.90173.c6

Aycrigg, J. L., Harper, S. J. \& Westervelt, J. D. (2004) Simulating land use alternatives and their impacts on a desert tortoise population in the Mojave Desert, California. In: Costanza, R. \& Voinov, A. (eds.) Landscape simulation modeling: A spatially-explicit, dynamic approach, pp. 249-273. New York, Springer. DOI: 10.1007/0-387-21555-7_10

Baker, J. P., Hulse, D. W., Gregory, S. V., White, D., Van Sickle, J., Berger, P. A., et al. (2004) Alternative futures for the Willamette River Basin, Oregon. Ecological Applications, 14(2), pp. 313-324. DOI: 10.1890/02-5011

Bao L. Q., Park, S. J. \& Vlec, P. L. G. (2010) Land Use Dynamic Simulator (LUDAS): A multi-agent system model for simulating spatio-temporal dynamics of coupled human-landscape system 2.Scenario-based application for impact assessment of land-use policies. Ecological Informatics, 5(3), pp. 203-221. DOI: 10.1016/j.ecoinf.2010.02.001

Barre, R. (2004) Participative and coherent scenario building: An input/ output balance model: The case of the French national futuris operation. 
Proceedings of the EU-US scientific seminar New Technology Foresight, Forecasting and Assessment Methods, Seville, Spain, 3-14 May. Typescript.

Bell, S. (1999) Landscape: Pattern, perception, and process. London, F \& FN SPON.

Bender, O., Boehmer, H. J., Jens, D. \& Schumacher, K. P. (2005) Using GIS to analyse long-term cultural landscape change in southern Germany. Landscape and Urban Planning, 70(1-2), pp. 111-125. DOI: 10.1016/j. landurbplan.2003.10.008

Berger, P. \& Bolte, J. (2004) Evaluating the impact of policy options on agricultural landscapes: An alternative futures approach. Ecological $A p-$ plications, 14(2), pp. 342-354. DOI: 10.1890/02-5069

Berger, A. \& Brown, C. (2008) Digital simulation and reclamation: Strategies for altered landscapes. In: Berger, A. (ed.) Designing the reclaimed landscape, pp. 115-124. New York, Taylor \& Francis.

Botequilha Leitão, A. \& Ahern, J. (2002) Applying landscape ecological concepts and metrics in sustainable landscape planning. Landscape and Urban Planning, 59(2), pp. 65-93. DOI: 10.1016/S0169-2046(02)00005-1

Botequilha Leitão, A., Miller, J., Ahern, J. \& McGarigal, K. (2006) Measuring landscapes: A planner's handbook. Washington, Island Press.

Breuste, J., Niemela, J. \& Snep, R. P. H. (2008) Applying landscape ecological principles in urban environments. Landscape Ecology, 23(10), pp. 1139-1142. DOI: 10.1007/s10980-008-9273-0

Broecker, W. (1975) Climatic change: Are we on the brink of a pronounced global warming? Science, 189, pp. 460-463.

DOI: $10.1126 /$ science. 189.4201 .460

Bryan, B. A., Crossman, N. D. \& King, D. (2008) Analyzing landscape futures for dry land agricultural areas: A case study in the Lower Murray region of southern Australia. In: Pettit, C., Cartwright, W., Bishop, I., Lowell, K., Pullar, D. \& Duncan, D. (eds.) Landscape analysis and visualisation: Spatial models for natural resource management and planning, pp. 407-434. New York, Springer. DOI: 10.1007/978-3-540-69168-6_20

Calthorpe, P. (2011) Urbanism in the age of climate change. Washington, Island Press. DOI: 10.5822/978-1-61091-005-7

Cartwright, A., Parnell, S., Oelofse, G. \& Ward, S. (2012) Climate change at the city scale: Impacts, mitigation and adaptation in Cape Town. Oxfordshire, Routledge.

Cartwright, W. (2008) Visualizing alternative futures. In: Pettit, C., Cartwright, W., Bishop, I., Lowell, K., Pullar, D. \& Duncan, D. (eds.) Landscape analysis and visualisation: Spatial models for natural resource management and planning, pp. 489-507. New York, Springer.

DOI: 10.1007/978-3-540-69168-6_24

Chen, G. (2012) State rescaling, contested space, and inequality in the globalizing city-regions of China: Conceptual issues and empirical evidence. Urbani izziv, 23(supplement 2), pp. S137-S149.

DOI: 10.5379/urbani-izziv-en-2012-23-supplement-2-012

Clarke, K. C. (2008) Mapping and modelling land use change: An application of the SLEUTH model. In: Pettit, C., Cartwright, W., Bishop, I., Lowell, K., Pullar, D. \& Duncan, D. (eds.) Landscape analysis and visualisation: Spatial models for natural resource management and planning, pp. 353-366. New York, Springer. DOI: 10.1007/978-3-540-69168-6_17

Condon, P., Cavens, D. \& Miller, N. (2009) Urban planning tools for climate change mitigation. Cambridge, Lincoln Institute of Land Policy.

Corry, R. C. \& Nassauer, J. I. (2005) Limitations of using landscape pattern indices to evaluate the ecological consequences of alternative plans and designs. Landscape and Urban Planning, 72(4), pp. 265-280. DOI: 10.1016/j.landurbplan.2004.04.003

Costanza, R. \& Voinov, A. (2004) Introduction: Spatially explicit land- scape simulation models. In: Costanza, R. \& Voinov, A. (eds.) Landscape simulation modeling: A spatially-explicit, dynamic approach, pp. 3-20. New York, Springer. DOI: 10.1007/0-387-21555-7_1

Crichton, D. Nicol, F. \& Roaf, S. (2009) Adapting buildings and cities for climate change. Oxford, Elsevier Ltd.

Dale, V., Brown, S., Haeuber, R., Hobbs, N., Huntly, N., Naiman, R., et al. (2000) Ecological Society of America report: Ecological principles and guidelines for managing the use of land. Ecological Applications, 10(3), pp. 639-670.

Deming, M. E. \& Swaffield, S. (2011) Landscape architecture research: Inquiry, strategy, design. Hoboken, NJ, John Wiley and Sons.

Deng, X., Su, H. \& Zhan, J. (2008) Integration of multiple data sources to simulate the dynamics of land systems. Sensors, 8(2), pp. 620-634. DOI: 10.1016/j.agee.2005.11.008

Dockerty, T., Lovett, A., Appleton, K., Bone, A. \& Sünnenberg, G. (2006) Developing scenarios and visualisations to illustrate potential policy and climatic influences on future agricultural landscapes. Agriculture Ecosystems \& Environment, 114(1) pp. 103-120.

Dramstad, W. E., Olson, J. D. \& Forman, R. T. T. (1996) Landscape ecology principles in landscape architecture and land-use planning. Cambridge, MA, Harvard University Graduate School of Design and Island Press.

Environmental Law Institute (2003) Conservation thresholds for land use planners. Washington $\mathrm{DC}$

Fabos, J. G. (1985) Land-use planning: From global to local challenge. New York, Chapman \& Hall.

Ferraz, S. F. B, Vettorazzi, C. A., Theobald, D. M. \& Ballester, M. V. R. (2005) Landscape dynamics of Amazonian deforestation between 1984 and 2002 in central Rondônia, Brazil: Assessment and future scenarios. Forest Ecology and Management, 204(1), pp. 69-85. DOI: 10.1016/j.foreco.2004.07.073

Flick, U. (1998) An introduction to qualitative research. London, Sage Publications.

Forman, R. T. T. (1995) Land mosaics: The ecology of landscapes and regions. Cambridge, Cambridge University Press.

Freemark, K., Hummon, C., White, D. \& Hulse, D. (1996) Modeling risks to biodiversity in past, present and future landscapes. Ottawa, Canadian Wildlife Service Headquarters.

Greeuw, S., van Asselt, M., Grosskurth, J., Storms, C., Rijkens-Klomp, M. Rothman, D., et al. (2000) Cloudy crystal balls: An assessment of recent European and global scenario studies and models. Copenhagen, European Environment Agency.

Guest, G., Bunce, A. \& Johnson, L. (2006) How many interviews are enough? An experiment with data saturation and variability. Field Methods, 18(1), pp. 59-82. DOI: $10.1177 / 1525822 X 05279903$

Hamin, E. M. \& Gurran, N. (2009) Urban form and climate change: Balancing adaptation and mitigation in the U.S. and Australia. Habitat International, 33(3), pp. 238-245. DOI: 10.1016/j.habitatint.2008.10.005

Harms, B. H., Knaapen, J. P. \& Rademakers, J. G. (1993) Landscape planning for nature restoration: Comparing regional scenarios. In: Vos, C. C. \& Opdam, P. (eds.) Landscape ecology of a stressed environment, pp. 197-218. London, Chapman \& Hall.

DOI: 10.1007/978-94-011-2318-1_9

Hodson, M. \& Marvin, S. (2010) World cities and climate change: Producing urban ecological security. Berkshire, Open University Press.

Hulse, D., Branscomb, A., Enright, C. \& Bolte, J. (2009) Anticipating floodplain trajectories: A comparison of two alternative futures approaches. Landscape Ecology, 24(8), pp. 1067-1090.

DOI: 10.1007/s10980-008-9255-2 
Hulse, D. W., Branscomb, A. \& Payne, S. (2004) Envisioning alternative futures: Using citizen guidance to map future land and water use. Ecological Applications, 14(2), pp. 325-341. DOI: 10.1890/02-5260

Hulse, D. W., Eilers, J., Freemark, K., White, D. \& Hummon, C. (2000) Planning alternative future landscapes in Oregon: Evaluating effects on water quality and biodiversity. Landscape Journal, 19(1-2), pp. 1-19.

Hulse, D., Goorjian, L., Richey, D., Flaxman, M., Hummon, C., White, D., et al. (1997) Possible futures for the Muddy Creek Watershed, Benton County. Eugene, The University of Oregon.

Hunter, L. M., Gonzalez, M. J., Stevenson, M., Karish, K. S., Toth, R., Edwards, T. C., et al. (2003) Population and land use change in the California Mojave: Natural habitat implications of alternative futures. Population Research and Policy Review, 22(4), pp. 373-397. DOI: 10.1023/A:1027311225410

Hwang, C. L. \& Yoon, K. (1981) Multiple attribute decision making: A state of the art survey. New York, Springer. DOI: 10.1007/978-3-642-48318-9

Jenerette, G. D. \& Potere, D. (2010) Global analysis and simulation of land-use change associated with urbanisation. Landscape Ecology, 25(5), pp. 657-670. DOI: 10.1007/s10980-010-9457-2

Jenerette, G. D. \& Wu, J. (2001) Analysis and simulation of land-use change in the central Arizona-Phoenix region, USA. Landscape Ecology, 16(7), pp. 611-626. DOI: 10.1023/A:1013170528551

Jongman, R. H. G. (2002) Homogenisation and fragmentation of the European landscapes: Ecological consequences and solutions. Landscape and Urban Planning, 58(2-4), pp. 211-221.

DOI: $10.1016 / 50169-2046(01) 00222-5$

Karvonen, L. (2000) Guidelines for ecological landscape planning. Vantaa, Metsähallitus.

Kepner, W. G., Hernandez, M., Semmens, D. J. \& Goodrich, D. (2008) The use of scenario analysis to assess future landscape change on a watershed condition in the Pacific Northwest (USA). In: Petrosillo, I., Müller, F., Jones, K. B., Zurlini, G., Krauze, K., Victorov, S., et al. (eds.) Use of landscape sciences for the assessment of environmental security, pp. 237-261. Amsterdam, Springer.

Kosow, H. \& Gabner, R. (2008) Methods of future and scenario analysis. Bonn, German Development Institute.

Kupfer, J. A. (2006) National assessments of forest fragmentation in the US. Global Environmental Change, 16(1), pp. 73-82.

DOI: 10.1016/j.gloenvcha.2005.10.003

Landis, J. (1995) Imagining land use futures: Applying the California Urban Futures model. Journal of the American Planning Association, 61(4), pp. 438-456. DOI: 10.1080/01944369508975656

Lee, T. (2014) Global cities and climate change: The trans-local relations of environmental governance. Oxfordshire, Routledge.

Lilieholm, R. J., Toth, R. \& Edwards, T. C. (2005) Alternative future growth scenarios for Utah's Wasatch Front: identifying future conflicts between development and the protection of environmental quality and public health. Ecology and the Environment, 84, pp. 1079-1088.

Linstone, H. A. \& Turoff, M. (2002) The Delphi method: Techniques and applications. Boston, Addison-Wesley Publishing Company.

Liu, Y. (2009) Modelling urban development with geographical information systems and cellular automata. New York, Taylor \& Francis.

Mansergh, I., Lau, A. \& Anderson, R. (2008) Geographic landscape visualisation in planning adaptation to climate change in Victoria, Australia. In: Pettit, C., Cartwright, W., Bishop, I., Lowell, K., Pullar, D. \& Duncan, D. (eds.) Landscape analysis and visualisation: Spatial models for natural resource management and planning, pp. 469-487. New York, Springer. DOI: 10.1007/978-3-540-69168-6_23
Maxwell, T., Voinov, A. \& Costanza, R. (2004) Spatial Simulation Using the SME. In: Costanza, R. \& Voinov, A. (eds.) Landscape simulation modeling: A spatially-explicit, dynamic approach, pp. 21-42. New York, Springer. DOI: 10.1007/0-387-21555-7_2

McHarg, I. (1969) Design with nature. Washington, Island Press.

Meadows, D. H., Meadows, D. L., Randers, J. \& Behrens, W. W. (1972) The limits to growth. New York, Universe Books.

Mehaffy, M. W. \& Haas, T. (2012) Poststructuralist fiddling while the world burns: Exiting the self made crisis of "architectural culture". Urbani izziv, 23(1), pp. 80-90. DOI: 10.5379/urbani-izziv-en-2012-23-01-001

Meyer, W., Bryan, B., Lyle, G., McLean, J., Moon, T., Siebentritt, M., et al. (2013) Adapted future landscapes from aspiration to implementation. Gold Coast, National Climate Change Adaptation Research Facility.

Morley, P., Trammell, E. J., Reeve, I., McNeill, J., Brunckhorst, D. \& Bassett, S. (2012) Past, present and future landscapes: Understanding alternative futures for climate change adaptation of coastal settlements and communities. Gold Coast, National Climate Change Adaptation Research Facility.

Moser, S. C. \& Boykoff, M. T. (2013) Successful adaptation to climate change: Linking science and policy in a rapidly changing world. Oxfordshire, Routledge.

Mouat, D. A., Bassett, S. \& Lancaster, J. (2006) The use of alternative futures in a strategy to assess the likelihood of increased land degradation leading to increased subsequent political instability. In: Kepner, W. G., Rubio, J. L., Mouat, D. A. \& Pedrazzini, F. (eds.) Desertification in the Mediterranean region: A security issue, pp. 601-614. Amsterdam, Springer. DOI: 10.1007/1-4020-3760-0_28

Mulligan, G. F. \& Crampton, J. P. (2005) Population growth in the world's largest cities. Cities, 22(5), pp. 365-380. DOI: 10.1016/j.cities.2005.07.001

Nassauer, J. I. \& Corry, R. C. (2004) Using normative scenarios in landscape ecology. Landscape Ecology, 19(4), pp. 343-356. DOI: 10.1023/B:LAND.0000030666.55372.ae

Oana, P. L., Harutyun, S., Brendan, W. \& Sheila, C. (2011) Scenarios and indicators supporting urban regional planning. Procedia Social and Behavioral Sciences, 21, pp. 243-252. DOI: 10.1016/j.sbspro.2011.07.012

Obeng-Odoom, F. (2012) Political economic origins of Sekondi-Takoradi, West Africa's new oil city. Urbani izziv, 23(2), pp. 121-130. DOI: 10.5379/urbani-izziv-en-2012-23-02-005

Odum, H. W. (1951) American sociology: The story of sociology in the United States through 1950. New York, Longmans, Green and Co.

Opdam, P., Luque, S. \& Jones, K. B. (2009) Changing landscapes to accommodate for climate change impacts: A call for landscape ecology. Landscape Ecology, 24(6), pp. 715-721. DOI: 10.1007/s10980-009-9377-1

Pan, Y., Yu, Z., Holst, J. \& Doluschitz, R. (2014) Integrated assessment of cropping patterns under different policy scenarios in Quzhou County, North China Plain. Land Use Policy, 40, pp. 131-139. DOI: 10.1016/j.landusepol.2013.11.015

Patel, M., Kok, K. \& Rothman, D. S. (2007) Participatory scenario construction in land use analysis: An insight into the experiences created by stakeholder involvement in the northern Mediterranean. Land Use Policy, 24(3), pp. 546-561. DOI: 10.1016/j.landusepol.2006.02.005

Penteado, H. M. (2013) Assessing the effects of applying landscape ecological spatial concepts on future habitat quantity and quality in an urbanizing landscape. Landscape Ecology, 28(10), pp. 1909-1921. DOI: 10.1007/s10980-013-9940-7

Pettit, C. J. \& Wyatt, R. (2009) A planning support system toolkit approach for formulating and evaluating land-use change scenarios. In: Geertman, S. \& Stillwell, J. (eds.) Planning support systems best practice 
and new methods, pp. 69-90. New York, Springer.

DOI: 10.1007/978-1-4020-8952-7_4

Pickett, S. T. A., Cadenasso, M. L., Grove, J. M., Nilon, C. H., Pouyat, R. V., Zipperer, W. C., et al. (2001) Urban ecological systems: Linking terrestrial ecological, physical, and socioeconomic components of metropolitan areas. Annual Review Ecological System, 32, pp. 127-157.

DOI: 10.1146/annurev.ecolsys.32.081501.114012

Pimentel, D. \& Pimentel, M. (2006) Global environmental resources versus world population growth. Ecological Economics, 59(2), pp. 195-198. DOI: 10.1016/j.ecolecon.2005.11.034

Pimerol, J. C. \& Romerio, S. B. (2000) Multicriteria decision in management: Principles and practice. Boston, Kluwer Academic Publishers. DOI: $10.1007 / 978-1-4615-4459-3$

Prutsch, A., Grothmann, T., McCallum, S., Schauser, I. \& Swart, R. (2014) Climate change adaptation manual: Lessons learned from European and other industrialized countries. Oxfordshire, Routledge.

Reyes, E., Martin, J. F., White, M. L., Day, J. W. \& Kemp, G. P. (2004) Habitat changes in the Mississippi delta: Future scenarios and alternatives. In: Costanza, R. \& Voinov, A. (eds.) Landscape simulation modeling: A spatially-explicit, dynamic approach, pp. 119-142. New York, Springer. DOI: 10.1007/0-387-21555-7_5

Rosenzweig, C., Solecki, W. D., Hammer, S. A. \& Mehrotra, S. (2011) Climate change and cities: First assessment report of the urban climate change research network. New York, Cambridge University Press. DOI: $10.1017 / C B O 9780511783142$

Santelmann, M. V., White, D., Freemark, K., Nassauer, J. I., Eilers, J. M., Vache, K. B., et al. (2004) Assessing alternative futures for agriculture in lowa, USA. Landscape Ecology, 19(4), pp. 357-374. DOI: 10.1023/B:LAND.0000030459.43445.19

Schooenboom, I. J. (1995) Overview and state of the art of scenario studies for the rural environment. In: Schoute, J. F., Finke, P. A., Veeneklaas, F. R. \& Wolfert, H. P. (eds.) Scenario studies for the rural environment, pp. 15-24. Dordrecht, Kluwer Academic Publishers.

Schumaker, N., Ernst, T., White, D., Baker, J. \& Haggerty, P. (2004) Projecting wildlife responses to alternative future landscapes in Oregon's Willamette Basin. Ecological Applications, 14(2), pp. 381-400. DOI: $10.1890 / 02-5010$

Sharma, T., Carmichael, J. \& Klinkenberg, B. (2005) A spatially explicit modeling approach to explore scenarios of sustainable agriculture futures. Journal of the Indian Society of Remote Sensing, 33(2), pp. 353 363. DOI: 10.1007/BF02990056

Sheikh-Goodarzi, M., Alizadeh-Shabani, A., Salman-Mahiny, A. \& Feghhi, J. (2012) Investigation of urban growth impacts on suitability of conservational patches using a landscape ecological approach (Study Area: Korganroud Watershed). Journal of Applied Ecology (Isfahan University of Technology), 1(1), pp. 30-43.

Shoyama, K. \& Yamagata, Y. (2014) Predicting land-use change for biodiversity conservation and climate-change mitigation and its effect on ecosystem services in a watershed in Japan. Ecosystem Services, 8, pp. 25-34. DOI: 10.1016/j.ecoser.2014.02.004

Sleeter, B. M., Sohl, T. L., Bouchard, M. A., Reker, R. R., Soulard, C. E., Acevedo, W., et al. (2012) Scenarios of land use and land cover change in the conterminous United States: Utilizing the special report on emission scenarios at ecoregional scales. Global Environmental Change, 22(4), pp. 896-914.

Soliva, R., Ronningen, K., Bella, I., Bezak, P., Cooper, T., Flo, B. E., et al. (2008) Envisioning upland futures: Stakeholder responses to scenarios for Europe's mountain landscapes. Journal of Rural Studies, 24(1), pp. 56-71. DOI: 10.1016/j.jrurstud.2007.04.001
Steinitz, C., Anderson, R., Arias, H., Bassett, S., Flaxman, M., Goode, T., et al. (2003) Alternative futures for changing landscapes: The San Pedro River Basin in Arizona and Sonora. Washington, DC, Island Press.

Steinitz, C., Binford, M., Cote, P., Edwards, T., Ervin, Jr. S., Forman, R. T. T., et al. (1996) Biodiversity and landscape planning: Alternative futures for the region of Camp Pendleton, California. Cambridge, MA, Harvard University, Graduate School of Design.

Sun, X. F., Yue, T. X. \& Fan, Z. F. (2012) Scenarios of changes in the spatial pattern of land use in China. Procedia Environmental Sciences, 13, pp. 590-597. DOI: 10.1016/j.proenv.2012.01.050

Theobald, D M. \& Hobbs, N. T. (2002) A framework for evaluating land use planning alternatives: Protecting biodiversity on private land. Con servation Ecology, 6(1), p. 5.

Tomlinson, R. (1968) A geographic information system for regional planning. In: Stewart, G. A. (ed.) Land Evaluation, pp. 200-210. Melbourne, Macmillan

Turner, M. G. (1989) Landscape ecology: The effect of pattern on process. Annual Review of Ecology and Systematics, 20, pp. 97-171. DOI: 10.1146/annurev.es.20.110189.001131

Verburg, P. H., van Berkel, D., B., van Doorn, A. M., van Eupen, M. \& van den Heiligenberg, H. A. R. M. (2010) Trajectories of land use change in Europe: A model-based exploration of rural futures. Landscape Ecology, 25(2), pp. 217-232. DOI: 10.1007/s10980-009-9347-7

Wang, H., Li, X., Long, H., Qiao, Y. \& Li, Y. (2011) Development and application of a simulation model for changes in land-use patterns under drought scenarios. Computers \& Geosciences, 37(7), pp. 831-843. DOI: 10.1016/j.cageo.2010.11.014

Wang, X. \& Hofe. R. V. (2007) Research methods in urban and regional planning. Beijing, Tsinghua University Press and Berlin, Springer. DOI: 10.1007/978-3-540-49658-8

Watson, D. \& Adams, M. (2011) Design for flooding: Architecture, land scape, and urban design for resilience to climate change. Hoboken, $\mathrm{NJ}$ John Wiley and Sons.

White, D., Minotti, P., G., Braczak, M., J., Sifneos, J. C., Freemark, K. E., Santelmann, M. V., et al. (1997) Assessing risks to biodiversity from future landscape change. Conservation Biology, 11(2), pp. 349-360. DOI: 10.1046/j.1523-1739.1997.95458.x

Wilson, E. \& Piper, J. (2010) Spatial planning and climate change. Oxfordshire, Routledge.

Wilson, V. (1997) Focus groups: A useful qualitative method for educational research? British Educational Research Journal, 23(2), pp. 209-224. DOI: 10.1080/0141192970230207

Zhang, J., Kotze, N. \& Yu, M. (2012) Living in a changing Chinese urban landscape: The Dalian case study. Urbani izziv, 23(2), pp. 93-102. DOI: 10.5379/urbani-izziv-en-2012-23-02-002 